Article

\title{
Plant Natural Sources of the Endocannabinoid (E)- $\beta$-Caryophyllene: A Systematic Quantitative Analysis of Published Literature
}

\author{
Massimo E. Maffei ${ }^{+}(\mathbb{C}$ \\ Department of Life Sciences and Systems Biology, University of Turin, Via Quarello 15/a, 10135 Turin, Italy; \\ massimo.maffei@unito.it; Tel.: +39-011-670-5967 \\ + This work is dedicated to Husnu Can Baser for his 70th birthday.
}

Received: 7 August 2020; Accepted: 4 September 2020; Published: 7 September 2020

\begin{abstract}
E)- $\beta$-caryophyllene (BCP) is a natural sesquiterpene hydrocarbon present in hundreds of plant species. $\mathrm{BCP}$ possesses several important pharmacological activities, ranging from pain treatment to neurological and metabolic disorders. These are mainly due to its ability to interact with the cannabinoid receptor 2 (CB2) and the complete lack of interaction with the brain CB1. A systematic analysis of plant species with essential oils containing a BCP percentage $>10 \%$ provided almost 300 entries with species belonging to 51 families. The essential oils were found to be extracted from 13 plant parts and samples originated from 56 countries worldwide. Statistical analyses included the evaluation of variability in $\mathrm{BCP} \%$ and yield\% as well as the statistical linkage between families, plant parts and countries of origin by cluster analysis. Identified species were also grouped according to their presence in the Belfrit list. The survey evidences the importance of essential oil yield evaluation in support of the chemical analysis. The results provide a comprehensive picture of the species with the highest $\mathrm{BCP}$ and yield percentages.
\end{abstract}

Keywords: plant species; essential oil; yield; percentages of (E)- $\beta$-caryophyllene; Belfrit list; plant part; geographical origin

\section{Introduction}

The endogenous cannabinoid system (ECS) plays an important role in the immune response to an infection. At present, two cannabinoid (CB) receptors are described: cannabinoid type 1 receptor (CB1) and cannabinoid type 2 receptor (CB2), both G-protein coupled receptors [1]. The CB2 receptor represents the peripheral $\mathrm{CB}$, due to its expression on circulating immune cells. However, studies have also found CB2 expression in the brain, such as cerebellum and microglial cells [2]. The CB2 receptor is involved in the attenuation of inflammatory immune responses. CB2 receptor pathway activation entails the suppression of cytokine release from immune cells and thereby dampening of the inflammatory response (immunosuppression) [3].

(E)- $\beta$-caryophyllene (BCP) is a bicyclic sesquiterpene hydrocarbon which is present in the essential oil of several plant species [4]. The Research Institute for Fragrance Materials (RIFM) evaluated BCP safety and the molecule has been approved by the Food and Drug Administration and by the European Food Safety Authority as a flavoring agent, which can be used in cosmetic and food additives [5]. Reports on oral sub-chronic toxicity support the safety of BCP for its proposed use also in medical food products [5]. $\mathrm{BCP}$ has been reported to be active against several disorders, with particular reference to cancer, chronic pain and inflammation [2]. Non-clinical BCP toxicity and an absence of adverse effects have been described [6]. Moreover, BCP can act as a selective agonist of CB2 [1], it activates peroxisome proliferator-activated receptor- $\alpha$ (PPAR $\alpha)$ [7] and has been recently involved in the prevention of 
lipid accumulation and in the improvement of glucose uptake [8]. Therefore, BCP is a plant-derived bioactive molecule able to improve health and prevent lifestyle diseases. Moreover, the specificity of $\mathrm{BCP}$ for the $\mathrm{CB} 2$ receptor, mainly expressed in peripheral tissues, and its inability to bind $\mathrm{CB} 1$, which is predominantly expressed at the level of the central nervous system, implies that its action is devoid of the known psychoactive effects associated with the activation of CB1 $[1,2,9,10]$. In this context, $B C P$ is an interesting alternative to the use of Cannabis.

Owing to the growing importance of $\mathrm{BCP}$, it was interesting to evaluate the occurrence of this important endocannabinoid in plant species used for the extraction of essential oils. Therefore, the aim of this work was to look for plant natural sources of BCP in order to provide the pharmaceutical, nutraceutical and aroma industries a summary of plant species, parts used for extraction and geographical origin of plants producing BCP. Moreover, additional information was provided with regards to the content and yield of $\mathrm{BCP}$ as well as the occurrence of selected species in the Belfrit list [11], which includes botanicals allowed in food supplements and ensures compliance of botanicals in terms of quality and safety.

\section{Results and Discussion}

The database search (performed in July 2020) for the term caryophyllene provided 5867 entries. The search was then refined by selecting all papers with a chemical composition description. This selection provided 2604 entries, which were individually analyzed in order to select papers providing information on $\mathrm{BCP}$ percentage $>10 \%$. Papers were then analyzed and the species binomial name, the plant family, the country of origin of samples and the plant part extracted were reported along with the BCP percentage and yield percentage. The total number of selected species was 295 (Table 1). Table 1 also lists the presence of the species in the Belfrit list [11].

In general, the 295 species belonged to 51 families and were reported from 56 countries worldwide. The essential oil containing BCP was extracted from 13 different plant parts. Out of 295 species, 34 were found to be listed in the Belfrit list, whereas for 51 species no data were available on the yield percentage. In many cases, the researchers used a small amount of plant parts (ranging from a few $g$ to 200-300 g) from which it was impossible to evaluate the oil yield. However, in the majority of the other cases the yield was provided and hence reported (Table 1). 
Table 1. Occurrence of (E)- $\beta$-caryophyllene (BCP) in different plant species. n.a., data not available, the essential oil (E.O.) yield is expressed as volume/weight percentage.

\begin{tabular}{|c|c|c|c|c|c|c|c|c|c|}
\hline Family & Genus & Species and Auth & Geogr. Origin of Sample & Belfrit List & Part Used & E.O. Yield\% & ВСР\% & Code & Ref. \\
\hline Anacardiaceae & Rhus & coriaria $\mathrm{L}$. & Iran & YES & fruits & 0.55 & 34.3 & 249 & [12] \\
\hline Anacardiaceae & Spondias & pinnata (Linn. F.) Kurz & Egypt & NO & leaves & 2.00 & 49.9 & 268 & [13] \\
\hline Annonaceae & Annona & muricata $\mathrm{L}$. & Bénin & YES & leaves & 0.10 & 13.6 & 30 & [14] \\
\hline Annonaceae & Annona & densicoma Mart. & Brazil & NO & leaves & 0.10 & 14.4 & 31 & [15] \\
\hline Annonaceae & Annona & senegalensis Pers. & Burkina Faso & NO & leaves & 0.73 & 19.1 & 32 & [16] \\
\hline Annonaceae & Annona & squamosa $\mathrm{L}$. & India & YES & leaves & 0.12 & 22.9 & 33 & [17] \\
\hline Annonaceae & Artabotrys & hexapetalus (L. f.) Bhandare & Vietnam & NO & flowers & 0.94 & 11.4 & 38 & [18] \\
\hline Annonaceae & Cananga & $\begin{array}{l}\text { odorata (Lam.) Hook.f. and } \\
\text { Thomson }\end{array}$ & Australia & YES & leaves & 0.30 & 52.0 & 62 & [19] \\
\hline Annonaceae & Cleistopholis & $\begin{array}{l}\text { glauca Pierre ex Engler and } \\
\text { Diels }\end{array}$ & Ivory Coast & $\mathrm{NO}$ & leaves & 0.19 & 26.2 & 81 & [20] \\
\hline Annonaceae & Fissistigma & rubiginosum Merr. & Vietnam & $\mathrm{NO}$ & leaves & 0.30 & 28.1 & 125 & [21] \\
\hline Annonaceae & Goniothalamus & multiovulatus Ast & Vietnam & $\mathrm{NO}$ & stems & 0.21 & 35.7 & 135 & [22] \\
\hline Annonaceae & Melodorum & $\begin{array}{l}\text { sp. (Dunal) Hook.f. and } \\
\text { Thomson }\end{array}$ & Australia & NO & leaf & 0.15 & 26.7 & 182 & [23] \\
\hline Annonaceae & Miliusa & $\begin{array}{l}\text { horsfieldii (Bennett) Baillon ex } \\
\text { Pierre }\end{array}$ & Australia & $\mathrm{NO}$ & leaves & 0.1 & 20.2 & 188 & [24] \\
\hline Annonaceae & Mitrephora & zippeliana Miq. & Australia & $\mathrm{NO}$ & leaves & 0.30 & 18.1 & 189 & [19] \\
\hline Annonaceae & Polyalthia & oliveri Engl. & Ivory Coast & $\mathrm{NO}$ & leaves & 0.13 & 31.4 & 237 & [25] \\
\hline Annonaceae & Pseuduvaria & hylandii Jessup & Australia & $\mathrm{NO}$ & leaves & 0.50 & 24.1 & 242 & [26] \\
\hline Annonaceae & Uvariodendron & calophyllum R. E. Fries & Cameroon & $\mathrm{NO}$ & stem barks & 0.52 & 32.5 & 284 & [27] \\
\hline Apiaceae & Berula & $\begin{array}{l}\text { erecta (Hudson) Coville subsp. } \\
\text { erecta }\end{array}$ & Serbia & $\mathrm{NO}$ & aerial parts & 0.01 & 14.9 & 52 & [28] \\
\hline Apiaceae & Bilacunaria & anatolica A. Duran & Turkey & $\mathrm{NO}$ & aerial parts & 0.14 & 10.3 & 54 & [29] \\
\hline Apiaceae & Centella & asiatica $\mathrm{L}$. & South Africa & YES & aerial parts & 0.06 & 19.1 & 75 & [30] \\
\hline Apiaceae & Conium & maculatum $\mathrm{L}$. & Iran & $\mathrm{NO}$ & aerial parts & 0.20 & 15.3 & 85 & [31] \\
\hline Apiaceae & Dorema & aucheri Boiss. & Iran & $\mathrm{NO}$ & leaves & 0.40 & 35.7 & 108 & [32] \\
\hline Apiaceae & Eryngium & vesiculosum Labill. & Australia & $\mathrm{NO}$ & aerial parts & n.a. & 20.3 & 116 & [33] \\
\hline Apiaceae & Ferula & glauca $\mathrm{L}$. & Iran & $\mathrm{NO}$ & leaves & 0.07 & 24.9 & 123 & [34] \\
\hline
\end{tabular}


Table 1. Cont

\begin{tabular}{|c|c|c|c|c|c|c|c|c|c|}
\hline Family & Genus & Species and Auth & Geogr. Origin of Sample & Belfrit List & Part Used & E.O. Yield \% & ВСР\% & Code & Ref \\
\hline Apiaceae & Grammosciadium & pterocarpum Boiss. & Turkey & $\mathrm{NO}$ & aerial parts & n.a. & 15.3 & 136 & {$[35]$} \\
\hline Apiaceae & Hippomarathrum & $\begin{array}{l}\text { microcarpum (M. Bieb.) B. } \\
\text { Fedtsch }\end{array}$ & Iran & $\mathrm{NO}$ & aerial parts & 0.85 & 15.75 & 145 & [36] \\
\hline Apiaceae & Hippomarathrum & boissieri Reuter et Hausskn & Turkey & $\mathrm{NO}$ & aerial parts & 0.40 & 25.6 & 146 & [37] \\
\hline Apiaceae & Laser & trilobum (L.) Borkh. & Iran & $\mathrm{NO}$ & aerial parts & 1.80 & 22.4 & 165 & [38] \\
\hline Apiaceae & Oenanthe & divaricata (R. Br.) Mabb. & Spain & NO & aerial parts & 0.20 & 15.3 & 206 & [39] \\
\hline Apiaceae & Ostericum & $\begin{array}{l}\text { viridiflorum (Turcz.) } \\
\text { Kitagawa }\end{array}$ & China & $\mathrm{NO}$ & aerial parts & 0.03 & 24.3 & 210 & {$[40]$} \\
\hline Apiaceae & Pimpinella & kotschyana Boiss. & Iran & $\mathrm{NO}$ & seeds & 5.16 & 49.9 & 224 & [41] \\
\hline Apiaceae & Prangos & uloptera DC. & Iran & NO & aerial parts & 0.70 & 18.2 & 240 & {$[42]$} \\
\hline Apiaceae & Zosima & absinthifolia Link & Iran & NO & aerial parts & 0.20 & 22.2 & 295 & {$[43]$} \\
\hline Apocynaceae & Allamanda & cathartica $\mathrm{L}$. & Brazil & NO & flowers & n.a. & 15.7 & 21 & {$[44]$} \\
\hline Apocynaceae & Aspidosperma & cylindrocarpon Muell. Arg. & Brazil & NO & leaves & 0.03 & 14.3 & 45 & [45] \\
\hline Apocynaceae & Tabernaemontana & catharinensis A. DC. & Brazil & NO & leaves & 0.30 & 56.9 & 272 & {$[46]$} \\
\hline Araliaceae & Schefflera & stellata (Gaertn.) Harms & India & NO & leaves & 0.10 & 19.2 & 260 & [47] \\
\hline Aristolochiaceae & Aristolochia & elegans Mast. & Argentina & $\mathrm{NO}$ & leaves & n.a. & 27.8 & 36 & [48] \\
\hline Aristolochiaceae & Aristolochia & fordiana Hemsl & China & NO & aerial parts & 0.19 & 11.1 & 37 & [49] \\
\hline Asteraceae & Achillea & asplenifolia Vent. & Serbia & $\mathrm{NO}$ & aerial parts & 0.10 & 17.6 & 4 & [50] \\
\hline Asteraceae & Achyrocline & alata (D.C.) & Brazil & $\mathrm{NO}$ & $\begin{array}{l}\text { leaf and } \\
\text { flowers }\end{array}$ & 4.00 & 16.0 & 5 & [51] \\
\hline Asteraceae & Acroptilon & repens $(\mathrm{L})$. & Iran & $\mathrm{NO}$ & aerial parts & 0.11 & 10.0 & 6 & [52] \\
\hline Asteraceae & Ageratum & $\begin{array}{l}\text { fastigiatum (Gardn.) R. M. } \\
\text { King et H. Rob }\end{array}$ & Brazil & $\mathrm{NO}$ & branches & 0.20 & 34.9 & 13 & [53] \\
\hline Asteraceae & Ageratum & conyzoides L. & Portugal & $\mathrm{NO}$ & flowers & 0.17 & 24.6 & 14 & [54] \\
\hline Asteraceae & Anthemis & altissima $\mathrm{L}$. & Iran & NO & flowers & 0.03 & 25.3 & 34 & {$[55]$} \\
\hline Asteraceae & Artemisia & verlotiorum Lamotte & France & YES & aerial parts & 0.20 & 12.7 & 39 & {$[56]$} \\
\hline Asteraceae & Artemisia & parviflora Roxb & India & NO & aerial parts & 0.20 & 15.3 & 40 & [57] \\
\hline Asteraceae & Artemisia & $\begin{array}{l}\text { roxburghiana Besser var. } \\
\text { purpurascens (Jacq.) Hook }\end{array}$ & India & $\mathrm{NO}$ & aerial parts & 0.85 & 18.4 & 41 & [58] \\
\hline Asteraceae & Artemisia & capillaris Thunb & South Korea & YES & aerial parts & n.a. & 11.1 & 42 & [59] \\
\hline Asteraceae & Artemisia. & stricta Edgew. f. stricta Pamp & India & NO & aerial parts & 0.46 & 13.4 & 43 & {$[60]$} \\
\hline Asteraceae & Artemisia. & lavandulaefolia DC & South Korea & $\mathrm{NO}$ & aerial parts & n.a. & 16.1 & 44 & [61] \\
\hline Asteraceae & Aspilia & africana (Pers.) C. D. Adams & Nigeria & NO & leaves & 0.02 & 10.8 & 46 & [62] \\
\hline
\end{tabular}


Table 1. Cont.

\begin{tabular}{|c|c|c|c|c|c|c|c|c|c|}
\hline Family & Genus & Species and Auth & Geogr. Origin of Sample & Belfrit List & Part Used & E.O. Yield\% & ВСР\% & Code & Ref. \\
\hline Asteraceae & Baccharis. & articulata (Lam.) Pers & Argentina & NO & aerial parts & n.a. & 16.8 & 48 & [63] \\
\hline Asteraceae & Bidens & pilosa $\mathrm{L}$. & Cameroon & NO & leaves & n.a. & 27.1 & 53 & [64] \\
\hline Asteraceae & Centaurea & $\begin{array}{l}\text { zlatiborensis Zlatkovic, } \\
\text { Novakovic and Janackovic }\end{array}$ & Serbia & NO & flowers & n.a. & 28.3 & 73 & {$[65]$} \\
\hline Asteraceae & Centaurea & appendicigera C. Koch & Turkey & NO & aerial parts & 0.18 & 17.5 & 74 & [66] \\
\hline Asteraceae & Centratherum & punctatum Cass & Nigeria & NO & leaves & n.a. & 16.6 & 76 & [67] \\
\hline Asteraceae & Chromolaena & odorata $\mathrm{L}$ & Togo & NO & aerial parts & 0.50 & 25.2 & 78 & [68] \\
\hline Asteraceae & Conyza & bonariensis (L.) Cronquist & Brazil & NO & aerial parts & 0.20 & 14.4 & 87 & [69] \\
\hline Asteraceae & Cyanthillium & cinereum (L.) H. Rob & Ivory Coast & NO & roots & n.a. & 17.0 & 100 & [70] \\
\hline Asteraceae & Dendranthema & indicum (L.) Des Moul. & China & $\mathrm{NO}$ & aerial parts & 0.08 & 13.8 & 106 & [71] \\
\hline Asteraceae & Emilia & sonchifolia (L.) DC. & India & NO & aerial parts & n.a. & 22.7 & 110 & [72] \\
\hline Asteraceae & Epaltes & alata Steetz & Niger & NO & leaves & 0.30 & 24.0 & 111 & [73] \\
\hline Asteraceae & Eremanthus & erythropappus (DC.) MacLeish & Brazil & $\mathrm{NO}$ & leaves & 0.12 & 29.3 & 113 & [74] \\
\hline Asteraceae & Erigeron & ramosus (Walt.) B.S.P. & Korea & NO & flowers & 0.40 & 24.0 & 114 & [75] \\
\hline Asteraceae & Eriocephalus & luederitzianus O.Hoffm. & South Africa & $\mathrm{NO}$ & aerial parts & 0.10 & 13.3 & 115 & [76] \\
\hline Asteraceae & Eupatorium & triplinerve Vahl & India & NO & leaves & 0.40 & 14.7 & 120 & [77] \\
\hline Asteraceae & Flourensia & campestris & Argentina & NO & aerial parts & 0.02 & 15.3 & 127 & [78] \\
\hline Asteraceae & Helichrysum & indutum Humbert & Madagascar & NO & aerial parts & 0.19 & 33.1 & 141 & [79] \\
\hline Asteraceae & Helichrysum & kraussii Sch. Bip. & South Africa & NO & aerial parts & n.a. & 30.7 & 142 & [80] \\
\hline Asteraceae & Helichrysum & melaleucum Rchb. ex Holl. & Spain & $\mathrm{NO}$ & aerial parts & 0.10 & 35.4 & 143 & [39] \\
\hline Asteraceae & Koanophyllon & villosum (Sw.) King et Robins & Cuba & $\mathrm{NO}$ & aerial parts & 0.45 & 17.0 & 160 & [81] \\
\hline Asteraceae & Laggera & oloptera (DC.) C. D. Adams & Cameroon & NO & leaves & 0.05 & 20.4 & 161 & [82] \\
\hline Asteraceae & Microglossa & $\begin{array}{l}\text { pyrrhapappa var. pyrrhopappa } \\
\text { (A. Rich) Agnew }\end{array}$ & Kenya & NO & leaves & 0.40 & 20.3 & 185 & [83] \\
\hline Asteraceae & Mikania & $\begin{array}{l}\text { cordata (Burm.f.) B.L. } \\
\text { Robinson var. cordata }\end{array}$ & Ivory Coast & NO & leaves & 0.63 & 11.8 & 187 & [84] \\
\hline Asteraceae & Oyedaea & verbesinoides DC. & Venezuela & NO & leaves & 0.05 & 27.1 & 211 & [85] \\
\hline Asteraceae & Perymenium & $\begin{array}{l}\text { grande Hemsl. var. nelsonii } \\
\text { (Robins. and Greenm.) Fay }\end{array}$ & Costa Rica & NO & leaves & 0.30 & 30.5 & 217 & [86] \\
\hline Asteraceae & Petasites & $\begin{array}{l}\text { japonicus (Siebold and Zucc.) } \\
\text { Maxim. }\end{array}$ & Japan & $\mathrm{NO}$ & leaves & 0.02 & 21.9 & 218 & [87] \\
\hline Asteraceae & Pluchea & carolinensis (Jacq.) Sweet & Martinique & NO & leaves & 0.11 & 21.1 & 236 & [88] \\
\hline
\end{tabular}


Table 1. Cont

\begin{tabular}{|c|c|c|c|c|c|c|c|c|c|}
\hline Family & Genus & Species and Auth & Geogr. Origin of Sample & Belfrit List & Part Used & E.O. Yield \% & ВСР\% & Code & Ref. \\
\hline Asteraceae & Porophyllum & obscurum (Spreng.) D.C. & Argentina & $\mathrm{NO}$ & leaves & 0.30 & 14.1 & 238 & [89] \\
\hline Asteraceae & Solidago & decurrens Lour & China & $\mathrm{NO}$ & leaves & 0.37 & 15.4 & 266 & [90] \\
\hline Asteraceae & Tagetes & patula $\mathrm{L}$. & Austria & NO & flowers & 0.15 & 53.5 & 273 & [91] \\
\hline Asteraceae & Tagetes & erecta $\mathrm{L}$. & Iran & YES & flowers & 0.35 & 35.2 & 274 & [92] \\
\hline Asteraceae & Tanacetum & punctatum (Desr.) Grierson & Iran & NO & aerial parts & 0.1 & 21.1 & 275 & [93] \\
\hline Asteraceae & Tarchonanthus & $\begin{array}{l}\text { trilobus var. galpinii (Hutch. } \\
\text { and E.Phillips) Paiva }\end{array}$ & South Africa & NO & leaves & 0.14 & 30.4 & 276 & [94] \\
\hline Asteraceae & Vernonia & chalybaea Mart. & Brazil & $\mathrm{NO}$ & aerial parts & 0.10 & 39.1 & 287 & [95] \\
\hline Asteraceae & Vernonia & scorpioides (Lam.) Pers. & Brazil & $\mathrm{NO}$ & aerial parts & 0.10 & 30.6 & 288 & [96] \\
\hline Asteraceae & Xanthium & strumarium $\mathrm{L}$. & Pakistan & $\mathrm{NO}$ & leaves & n.a. & 17.5 & 291 & [97] \\
\hline Asteraceae, & Leptocarpha & rivularis DC. & Chile & $\mathrm{NO}$ & aerial parts & 0.15 & 21.1 & 168 & [98] \\
\hline Atherospermataceae & Daphnandra & repandula (F.Muell.) F.Muell. & Australia & $\mathrm{NO}$ & aerial parts & 0.20 & 12.2 & 105 & [99] \\
\hline Boraginaceae & Cordia & leucocephala Moric & Brazil & $\mathrm{NO}$ & leaves & 0.04 & 39.0 & 91 & [100] \\
\hline Boraginaceae & Cordia & multispicata Cham. & Brazil & $\mathrm{NO}$ & leaves & 0.25 & 56.6 & 92 & [101] \\
\hline Burseraceae & Bursera & aromatica (Proctor) & Jamaica & $\mathrm{NO}$ & leaves & 0.03 & 21.7 & 59 & [102] \\
\hline Burseraceae & Bursera & microphylla A. Gray & USA & $\mathrm{NO}$ & oleo-gum-resin & 2.10 & 72.9 & 60 & [103] \\
\hline Burseraceae & Canarium & parvum Leen. & Vietnam & $\mathrm{NO}$ & leaves & 0.20 & 18.7 & 63 & [104] \\
\hline Burseraceae & Dacryodes & edulis (G. Don) H. J. Lam & Nigeria & $\mathrm{NO}$ & leaves & 0.08 & 26.0 & 103 & [105] \\
\hline Burseraceae & Protium & heptaphyllum (Aubl.) March. & Brazil & YES & leaves & 0.30 & 18.6 & 241 & [106] \\
\hline Cannabaceae & Cannabis & sativa L. ssp. spontanea & Austria & YES & aerial parts & n.a. & 16.2 & 64 & [107] \\
\hline Cannabaceae & Cannabis & sativa $\mathrm{L}$. & Italy & YES & flowers & 0.10 & 23.8 & 65 & [108] \\
\hline Cannabaceae & Humulus & lupulus $\mathrm{L}$. & USA & YES & aerial parts & n.a. & 22.0 & 148 & [109] \\
\hline Caryophyllaceae & Dianthus & caryophyllus L. & Iran & YES & aerial parts & n.a. & 34.8 & 107 & [110] \\
\hline Cephalotaxaceae & Cephalotaxus & $\begin{array}{l}\text { harringtonia K.Koch subsp. } \\
\text { harringtonia }\end{array}$ & India & $\mathrm{NO}$ & twigs & 0.01 & 21.1 & 77 & [111] \\
\hline Clusiaceae & Clusia & nemorosa G. Mey & Brazil & NO & fruits & 0.30 & 48.6 & 83 & [112] \\
\hline Clusiaceae & Garcinia & atroviridis Griff. ex T. Anders. & Malaysia & $\mathrm{NO}$ & fruits & n.a. & 23.8 & 128 & [113] \\
\hline Clusiaceae & Kielmeyera & rugosa Choisy & Brazil & $\mathrm{NO}$ & fruits & n.a. & 16.4 & 158 & [114] \\
\hline Clusiaceae & Pentadesma & butyracea Sabine & Benin & $\mathrm{NO}$ & barks & 0.08 & 74.0 & 214 & [115] \\
\hline Clusiaceae & Psorospermum & corymbiferum Hochr & Nigeria & $\mathrm{NO}$ & leaves & 0.02 & 46.8 & 245 & [116] \\
\hline Convolvulaceae & Convolvulus & persicus L. & Iran & $\mathrm{NO}$ & aerial parts & 0.04 & 47.0 & 86 & [117] \\
\hline
\end{tabular}


Table 1. Cont

\begin{tabular}{|c|c|c|c|c|c|c|c|c|c|}
\hline Family & Genus & Species and Auth & Geogr. Origin of Sample & Belfrit List & Part Used & E.O. Yield\% & ВСР\% & Code & Ref. \\
\hline Cupressaceae & Cedrus & atlantica G. Manetti & Algeria & $\mathrm{NO}$ & twigs & 0.02 & 11.4 & 72 & [118] \\
\hline Cupressaceae & Juniperus & $\begin{array}{l}\text { macrocarpa Sibth. and Sm. } \\
\text { (Jom) }\end{array}$ & Turkey & $\mathrm{NO}$ & fruits & n.a. & 29.6 & 156 & [119] \\
\hline Cupressaceae & Thuja & orientalis L. & Egypt & $\mathrm{NO}$ & aerial parts & 2.60 & 24.0 & 281 & [120] \\
\hline Cyperaceae & Cyperus & glomeratus $\mathrm{L}$. & Serbia & NO & $\begin{array}{l}\text { rhizomes } \\
\text { and roots }\end{array}$ & 0.06 & 12.6 & 102 & [121] \\
\hline Ehretiaceae & Varronia & curassavica Jacq. & Brazil & $\mathrm{NO}$ & leaves & 0.6 & 41.2 & 285 & [122] \\
\hline Ehretiaceae & Varronia & schomburgkii (DC.) Borhidi & French Guiana & $\mathrm{NO}$ & aerial parts & 0.06 & 47.0 & 286 & [123] \\
\hline Euphorbiaceae & Acalypha & fruticos $a$ Forssk & India & $\mathrm{NO}$ & leaves & 1.40 & 42.0 & 2 & [124] \\
\hline Euphorbiaceae & Alchornea & tiliifolia (Benth.) Muell. & Vietnam & $\mathrm{NO}$ & aerial parts & n.a. & 10.7 & 20 & [125] \\
\hline Euphorbiaceae & Croton & $\begin{array}{l}\text { rhamnifolioides Pax and } \\
\text { Hoffm }\end{array}$ & Brazil & $\mathrm{NO}$ & leaf & 0.21 & 33.3 & 94 & [126] \\
\hline Euphorbiaceae & Croton & glandulosus L. & Brazil & $\mathrm{NO}$ & aerial parts & 0.12 & 53.2 & 95 & [127] \\
\hline Euphorbiaceae & Croton & pulegiodorus Baill. & Brazil & $\mathrm{NO}$ & aerial parts & 5.00 & 20.9 & 96 & [128] \\
\hline Euphorbiaceae & Phyllanthus & $\begin{array}{l}\text { muellerianus (O. Kuntze) } \\
\text { Exell }\end{array}$ & Nigeria & $\mathrm{NO}$ & leaves & 0.12 & 41.9 & 223 & [129] \\
\hline Fabaceae & Bauhinia & rufa Steud. & Brazil & $\mathrm{NO}$ & leaves & 0.01 & 15.8 & 50 & [130] \\
\hline Fabaceae & Bowdichia & virgilioides Kunt & Brazil & YES & seeds & 2.20 & 44.1 & 57 & [131] \\
\hline Fabaceae & Caesalpinia & decapetala (Roth) Alston & Japan & $\mathrm{NO}$ & aerial parts & 0.07 & 17.2 & 61 & [132] \\
\hline Fabaceae & Copaifera & langsdorffii Desf. & Brazil & YES & oleoresins & 28.00 & 72.0 & 88 & [133] \\
\hline Fabaceae & Copaifera & multijuga Hayne & Brazil & $\mathrm{NO}$ & oleoresins & n.a. & 57.5 & 89 & [134] \\
\hline Fabaceae & Copaifera & reticulata Ducke & Brazil & $\mathrm{NO}$ & oleoresins & n.a. & 68.0 & 90 & [135] \\
\hline Fabaceae & Dalea & carthagenensis L. & Colombia & $\mathrm{NO}$ & leaves & 0.15 & 20.7 & 104 & [136] \\
\hline Fabaceae & Eperua & duckeana Cowan & Brazil & $\mathrm{NO}$ & leaves & n.a. & 31.8 & 112 & [137] \\
\hline Fabaceae & Glycyrrhiza & triphylla Fisch. and C.A.Mey & Iran & $\mathrm{NO}$ & aerial parts & 0.50 & 25.4 & 134 & [138] \\
\hline Fabaceae & Psoralea & bituminosa $L$ & Italy & $\mathrm{NO}$ & leaves & 0.10 & 23.2 & 244 & [139] \\
\hline Fabaceae & Rynchosia & minima DC. & Kenya & $\mathrm{NO}$ & aerial parts & 0.10 & 30.4 & 252 & [140] \\
\hline Flacourtiaceae & Casearia & decandra Jacq. & Brazil & $\mathrm{NO}$ & leaves & 0.20 & 13.0 & 67 & [141] \\
\hline Flacourtiaceae & Casearia & sylvestris Swart. & Brazil & $\mathrm{NO}$ & leaves & 0.60 & 27.5 & 68 & [142] \\
\hline Geraniaceae & Geranium & wallichianum D. Don ex Sweet & India & $\mathrm{NO}$ & aerial parts & n.a. & 15.9 & 130 & [143] \\
\hline Gramineae & Elyonurns & muticus (Sprengel) O.Kuntze & Brazil & $\mathrm{NO}$ & leaves & 0.45 & 17.9 & 109 & [144] \\
\hline
\end{tabular}


Table 1. Cont

\begin{tabular}{|c|c|c|c|c|c|c|c|c|c|}
\hline Family & Genus & Species and Auth & Geogr. Origin of Sample & Belfrit List & Part Used & E.O. Yield\% & ВСР\% & Code & Ref. \\
\hline Gramineae & Melinis & minutiflora P. Beauv & Kenya & $\mathrm{NO}$ & aerial parts & 0.01 & 24.2 & 180 & [145] \\
\hline Hernandiaceae & Hernandia & $\begin{array}{l}\text { nymphaeifolia (C.Presl) } \\
\text { Kubitzki }\end{array}$ & Australia & NO & leaves & 0.01 & 43.8 & 144 & [146] \\
\hline Hypericaceae & Hypericum & brasiliense Choisy & Brazil & $\mathrm{NO}$ & aerial parts & 0.10 & 29.5 & 150 & [147] \\
\hline Hypericaceae & Hypericum & perforatum $\mathrm{L}$. & Iran & YES & aerial parts & n.a. & 25.05 & 151 & [148] \\
\hline Hypericaceae & Vismia & $\begin{array}{l}\text { baccifera subsp. dealbata } \\
\text { (Kunth) Ewan }\end{array}$ & Venezuela & $\mathrm{NO}$ & leaves & 0.07 & 45.7 & 289 & [149] \\
\hline Juglandaceae & Juglans & regia $\mathrm{L}$. & India & YES & leaves & 0.02 & 15.5 & 155 & [150] \\
\hline Lamiaceae & Aegiphila & lhotzkiana Cham. & Brazil & $\mathrm{NO}$ & leaves & 0.02 & 27.5 & 9 & [151] \\
\hline Lamiaceae & Ajuga & parviflora Benth. & India & $\mathrm{NO}$ & aerial parts & n.a. & 22.4 & 18 & [152] \\
\hline Lamiaceae & Ajuga & comata Stapf. & Iran & $\mathrm{NO}$ & aerial parts & n.a. & 30.9 & 19 & [153] \\
\hline Lamiaceae & Ballota & nigra L. & Algeria & YES & aerial parts & n.a. & 24.6 & 49 & [154] \\
\hline Lamiaceae & Clerodendrum & polycephalum Baker & Nigeria & $\mathrm{NO}$ & leaves & 0.16 & 28.9 & 82 & [155] \\
\hline Lamiaceae & Colquhounia & coccinea Wall. & India & $\mathrm{NO}$ & flower & 0.20 & 53.2 & 84 & [156] \\
\hline Lamiaceae & Cunila & incana Benth. & Brazil & $\mathrm{NO}$ & aerial parts & 0.72 & 11.3 & 98 & [157] \\
\hline Lamiaceae & Cyclotrichium. & strussii Bornm & Iran & $\mathrm{NO}$ & aerial parts & 0.37 & 16.9 & 101 & [158] \\
\hline Lamiaceae & Glechoma & hederacea L. & Lithuania & $\mathrm{NO}$ & aerial parts & 0.05 & 14.2 & 131 & [159] \\
\hline Lamiaceae & Glechon & marifolia Benth. & Brazil & $\mathrm{NO}$ & leaves & 1.40 & 32.2 & 132 & [160] \\
\hline Lamiaceae & Hoslundia & opposita Vahl. & Ivory Coast & $\mathrm{NO}$ & leaves & 0.04 & 24.8 & 147 & [161] \\
\hline Lamiaceae & Hymenocrater & calycinus (Boiss.) Benth. & Iran & $\mathrm{NO}$ & aerial parts & 0.20 & 32.8 & 149 & [162] \\
\hline Lamiaceae & Hyptidendron & $\begin{array}{l}\text { canum (Pohl ex Benth.) } \\
\text { Harley }\end{array}$ & Brazil & NO & leaves & 0.82 & 41.6 & 152 & [163] \\
\hline Lamiaceae & Hyptis & mutabilis (Rich.) Briq. & Argentina & NO & aerial parts & n.a. & 59.4 & 153 & [164] \\
\hline Lamiaceae & Hyptis & suaveolens (L.) Poit. & Bénin & YES & fruits & 0.10 & 43.7 & 154 & [165] \\
\hline Lamiaceae & Lallenmantia & $\begin{array}{l}\text { iberica (M. Bieb.) Fisch and } \\
\text { CA Mey }\end{array}$ & Turkey & $\mathrm{NO}$ & aerial parts & n.a. & 18.3 & 162 & [166] \\
\hline Lamiaceae & Leonotis & $\begin{array}{l}\text { ocymifolia (Burm.f.) } \\
\text { M.Iwarsson }\end{array}$ & South Africa & $\mathrm{NO}$ & leaves & 0.06 & 30.8 & 166 & [167] \\
\hline Lamiaceae & Leonurus & sibiricus L. & Argentina & $\mathrm{NO}$ & aerial parts & n.a. & 35.2 & 167 & [164] \\
\hline Lamiaceae & Leucas & aspera (Willd.) Link & India & $\mathrm{NO}$ & aerial parts & 0.30 & 34.2 & 169 & [168] \\
\hline Lamiaceae & Leucas & indica (L.) R.Br & India & $\mathrm{NO}$ & aerial parts & n.a. & 51.1 & 170 & [169] \\
\hline Lamiaceae & Marrubium & $\begin{array}{l}\text { bourgaei subsp. caricum } \\
\text { P.H.Davis }\end{array}$ & Tunisia & $\mathrm{NO}$ & aerial parts & 0.07 & 23.2 & 175 & [170] \\
\hline Lamiaceae & Marsypianthes & chamnedrys (Vahl) Kuntze & Brazil & $\mathrm{NO}$ & aerial parts & n.a. & 15.1 & 176 & [171] \\
\hline
\end{tabular}


Table 1. Cont

\begin{tabular}{|c|c|c|c|c|c|c|c|c|c|}
\hline Family & Genus & Species and Auth & Geogr. Origin of Sample & Belfrit List & Part Used & E.O. Yield\% & ВСР\% & Code & Ref. \\
\hline Lamiaceae & Melissa & romana Miller & Italy & $\mathrm{NO}$ & aerial parts & 0.30 & 15.8 & 181 & [172] \\
\hline Lamiaceae & Mentha & longifolia (L.) Hudson & Iran & $\mathrm{NO}$ & aerial parts & 0.41 & 23.2 & 183 & [173] \\
\hline Lamiaceae & Micromeria & myrtifolia Boiss. and Hohen. & Turkey & $\mathrm{NO}$ & aerial parts & 0.20 & 40.8 & 186 & [174] \\
\hline Lamiaceae & Mosla & soochowensis Matsuda & China & $\mathrm{NO}$ & aerial parts & 0.05 & 12.8 & 191 & [175] \\
\hline Lamiaceae & Nepeta & fissa C.A. Mey & Iran & $\mathrm{NO}$ & aerial parts & 0.25 & 33.1 & 200 & [176] \\
\hline Lamiaceae & Nepeta & curviflora Boiss. & Lebanon & $\mathrm{NO}$ & aerial parts & 0.30 & 50.2 & 201 & [177] \\
\hline Lamiaceae & Осітит & tenuiflorum L. & India & YES & aerial parts & 0.33 & 30.0 & 203 & [178] \\
\hline Lamiaceae & Origanum & majorana $\mathrm{L}$. & Algeria & YES & aerial parts & 1.20 & 26.0 & 207 & [179] \\
\hline Lamiaceae & Orthodon & dianfhera Maxim. & Vietnam & $\mathrm{NO}$ & aerial parts & 0.20 & 52.9 & 208 & [180] \\
\hline Lamiaceae & Orthosiphon & pallidus Royle, ex Benth & India & $\mathrm{NO}$ & aerial parts & n.a. & 17.4 & 209 & [181] \\
\hline Lamiaceae & Perilla & $\begin{array}{l}\text { frutescens var. japonica } \\
\text { (Hassk.) H.Hara }\end{array}$ & China & YES & leaves & 0.11 & 37.2 & 215 & [182] \\
\hline Lamiaceae & Phlomis & $\begin{array}{l}\text { crinita Cav. ssp. mauritanica } \\
\text { Munby }\end{array}$ & Tunisia & $\mathrm{NO}$ & aerial parts & 0.10 & 40.8 & 220 & [183] \\
\hline Lamiaceae & Phlomis & rigida Labill. & Turkey & $\mathrm{NO}$ & aerial parts & 0.05 & 38.7 & 221 & [184] \\
\hline Lamiaceae & Platostoma & menthoides (L.) A. J. Paton & Sri Lanka & $\mathrm{NO}$ & aerial parts & 0.50 & 37.0 & 233 & [185] \\
\hline Lamiaceae & Plectranthus & rugosus Wall. & India & $\mathrm{NO}$ & leaves & n.a. & 38.4 & 234 & [186] \\
\hline Lamiaceae & Pycnostachys & eminii Gürke & Ethiopia & $\mathrm{NO}$ & leaves & 0.13 & 21.6 & 246 & [187] \\
\hline Lamiaceae & Rosmarinus & officinalis L & Lebanon & YES & aerial parts & 0.09 & 12.9 & 251 & [188] \\
\hline Lamiaceae & Salvia & palaefolia Kunth & Colombia & $\mathrm{NO}$ & aerial parts & 0.06 & 32.2 & 253 & [189] \\
\hline Lamiaceae & Salvia & bracteata Banks and Soland & Iran & $\mathrm{NO}$ & aerial parts & 0.28 & 41.4 & 254 & [190] \\
\hline Lamiaceae & Salvia & hydrangea DC. ex Benth. & Iran & $\mathrm{NO}$ & aerial parts & 0.20 & 33.4 & 255 & [191] \\
\hline Lamiaceae & Salvia & nemorosa L. & Iran & $\mathrm{NO}$ & aerial parts & 0.12 & 41.6 & 256 & [192] \\
\hline Lamiaceae & Salvia & virgata Jacq. & Iran & $\mathrm{NO}$ & aerial parts & 0.48 & 46.6 & 257 & [193] \\
\hline Lamiaceae & Salvia & canariensis L. & Spain & $\mathrm{NO}$ & aerial parts & 4.00 & 30.2 & 258 & [194] \\
\hline Lamiaceae & Salvia & montbretii Benth. & Turkey & $\mathrm{NO}$ & aerial parts & 0.10 & 32.8 & 259 & [195] \\
\hline Lamiaceae & Scutellaria & havanensis Jacq. & Cuba & $\mathrm{NO}$ & leaves & 0.18 & 75.6 & 261 & [196] \\
\hline Lamiaceae & Scutellaria & $\begin{array}{l}\text { brevibracteata Stapf. subsp. } \\
\text { pannosula } \\
\text { clandestina subsp. }\end{array}$ & Turkey & $\mathrm{NO}$ & aerial parts & n.a. & 36.4 & 262 & [197] \\
\hline Lamiaceae & Sideritis & $\begin{array}{l}\text { peloponnesiaca (Boiss. and } \\
\text { Heldr.) Baden }\end{array}$ & Greece & $\mathrm{NO}$ & aerial parts & 1.00 & 16.4 & 263 & [198] \\
\hline Lamiaceae & Sideritis & phlomoides Boiss. and Bal. & Turkey & $\mathrm{NO}$ & aerial parts & 0.20 & 30.7 & 264 & [199] \\
\hline Lamiaceae & Stachys & viticina Boiss. & Turkey & $\mathrm{NO}$ & aerial parts & 0.20 & 62.3 & 269 & [200] \\
\hline
\end{tabular}


Table 1. Cont.

\begin{tabular}{|c|c|c|c|c|c|c|c|c|c|}
\hline Family & Genus & Species and Auth & Geogr. Origin of Sample & Belfrit List & Part Used & E.O. Yield\% & ВСР\% & Code & Ref. \\
\hline Lamiaceae & Teucrium & arduini $\mathrm{L}$. & Croatia & NO & aerial parts & 0.35 & 35.4 & 277 & [201] \\
\hline Lamiaceae & Teucrium & flavum $\mathrm{L}$. & Iran & $\mathrm{NO}$ & leaves & 0.20 & 30.7 & 278 & [202] \\
\hline Lamiaceae & Teucrium & siculum (Raf.) Guss. & Italy & NO & aerial parts & 0.10 & 30.9 & 279 & [203] \\
\hline Lamiaceae & Teucrium & $\begin{array}{l}\text { turredanum Losa and } \\
\text { Rivas-Goday }\end{array}$ & Spain & NO & aerial parts & 0.60 & 32.0 & 280 & [204] \\
\hline Lamiaceae & Viticipremna & queenslandica Munir & Australia & $\mathrm{NO}$ & leaves & n.a. & 33.6 & 290 & [205] \\
\hline Lamiaceae & Ziziphora & taurica M.Bieb. subsp. taurica & Turkey & $\mathrm{NO}$ & aerial parts & 0.80 & 24.8 & 294 & [206] \\
\hline Lauraceae & Aiouea & costaricensis (Mez) Kosterm. & Costa Rica & NO & leaf & 0.10 & 12.0 & 17 & [207] \\
\hline Lauraceae & Alseodaphne & peduncularis Meisn & Malaysia & $\mathrm{NO}$ & leaves & n.a. & 24.0 & 27 & [208] \\
\hline Lauraceae & Aniba & riparia (Nees) Mez & Brazil & $\mathrm{NO}$ & leaves & 0.30 & 16.9 & 29 & [209] \\
\hline Lauraceae & Beilschmiedia & penangiana Gamble & Malaysia & NO & aerial parts & 0.10 & 12.6 & 51 & [210] \\
\hline Lauraceae & Cassytha & pubescens R.Br. & Australia & $\mathrm{NO}$ & aerial parts & 0.10 & 30.9 & 69 & [211] \\
\hline Lauraceae & Сіппатотит & $\begin{array}{l}\text { tamala (Ham) Nees and } \\
\text { Eberm. }\end{array}$ & Pakistan & NO & leaves & 0.03 & 25.3 & 79 & [212] \\
\hline Lauraceae & Litsea & helferi Hook.f. & Vietnam & NO & leaves & 0.30 & 14.2 & 172 & [213] \\
\hline Lauraceae & Nectandra & lanceolata Ness & Brazil & NO & leaves & 0.20 & 32.5 & 198 & [214] \\
\hline Lauraceae & Neolitsea & $\begin{array}{l}\text { foliosa (Nees) Gamble var. } \\
\text { caesia (Meisner) Gamble }\end{array}$ & India & NO & leaves & 0.10 & 35.3 & 199 & [215] \\
\hline Lauraceae & Ocotea & duckei Vattimo-Gil & Brazil & NO & leaves & 0.70 & 60.5 & 204 & [216] \\
\hline Lauraceae & Ocotea & splendens (Meisn.) Baill & Brazil & NO & leaves & 0.35 & 51.0 & 205 & [217] \\
\hline Lauraceae & Persea & americana Mill. & Nigeria & YES & leaves & 0.20 & 43.9 & 216 & [218] \\
\hline Lauraceae & Phoebe & porphyria (Griseb.) Mez. & Argentina & $\mathrm{NO}$ & aerial parts & 0.15 & 19.3 & 222 & [219] \\
\hline Magnoliaceae & Magnolia & obovata Thunb. & Japan & NO & leaves & 0.05 & 23.7 & 173 & [220] \\
\hline Malvaceae & Pachira & glabra Pasq. & Nigeria & $\mathrm{NO}$ & leaves & 0.71 & 14.5 & 212 & [221] \\
\hline Malvaceae & Triumfetta & rhomboidea Jacq. & Burkina-Faso & $\mathrm{NO}$ & aerial parts & 0.02 & 24.2 & 282 & [222] \\
\hline Meliaceae & Aglaia & odorata Lour. & Thailand & NO & stem & 0.07 & 10.2 & 15 & [223] \\
\hline Meliaceae & Aphanamixis & polystachya (Wall.) R.Parker & Bangladesh & $\mathrm{NO}$ & wood & n.a. & 19.4 & 35 & [224] \\
\hline Meliaceae & Cedrela & fissilis Vellozo & Brazil & NO & leaves & 0.06 & 26.3 & 70 & [225] \\
\hline Meliaceae & Guarea & $\begin{array}{l}\text { macrophylla Vahl. ssp. } \\
\text { tuberculata Vellozo }\end{array}$ & Brazil & NO & leaves & 0.15 & 10.0 & 137 & [226] \\
\hline Moraceae & Ficus & benjamina $\mathrm{L}$. & Nigeria & NO & leaves & n.a. & 17.0 & 124 & [227] \\
\hline Myricaceae & Morella & pensylvanica (Mirbel) Kartesz & Canada & $\mathrm{NO}$ & aerial parts & 0.15 & 14.5 & 190 & [228] \\
\hline Myristicaceae & Gymnacranthera & canarica (King) Warb. & India & NO & leaves & 0.01 & 23.4 & 138 & [229] \\
\hline
\end{tabular}


Table 1. Cont

\begin{tabular}{|c|c|c|c|c|c|c|c|c|c|}
\hline Family & Genus & Species and Auth & Geogr. Origin of Sample & Belfrit List & Part Used & E.O. Yield \% & ВСР\% & Code & Ref. \\
\hline Myristicaceae & Кпета & kunstleri Warb. & Malaysia & $\mathrm{NO}$ & aerial parts & 0.12 & 23.2 & 159 & [230] \\
\hline Myristicaceae & Myristica & malabarica Lam. & India & $\mathrm{NO}$ & leaves & 0.05 & 27.3 & 197 & [229] \\
\hline Myrtaceae & Blepharocalyx & salicifolius O.Berg & Brazil & $\mathrm{NO}$ & leaves & 0.90 & 22.9 & 55 & [231] \\
\hline Myrtaceae & Eucalyptus & leptophleba F. Muell. & Australia & $\mathrm{NO}$ & leaves & 0.01 & 11.4 & 118 & [232] \\
\hline Myrtaceae & Eugenia & stipitata McVaugh ssp. sororia & Portugal & $\mathrm{NO}$ & leaves & 0.35 & 22.7 & 119 & [233] \\
\hline Myrtaceae & Feijoa & sellowiana Berg. & France & NO & fruits & 0.10 & 12.0 & 121 & [234] \\
\hline Myrtaceae & Marlierea & $\begin{array}{l}\text { silvatica Kiaersk } \\
\text { sphaerodendra var. microphylla }\end{array}$ & Brazil & $\mathrm{NO}$ & leaves & 0.30 & 25.4 & 174 & [235] \\
\hline Myrtaceae & Melaleuca & $\begin{array}{l}\text { (Virot) Craven and J.W. } \\
\text { Dawson }\end{array}$ & New Caledonia & $\mathrm{NO}$ & leaves & 0.10 & 28.8 & 178 & [236] \\
\hline Myrtaceae & Myrcia & сирrea (O. Berg) Kiaersk. & Brazil & $\mathrm{NO}$ & aerial parts & 0.10 & 39.1 & 194 & [237] \\
\hline Myrtaceae & Myrcianthes & pseudo-mato (Legr.) Mc. Vaugh & Argentina & $\mathrm{NO}$ & leaves & 0.30 & 18.9 & 195 & [238] \\
\hline Myrtaceae & Myrciaria & tenella (DC.) Berg & Brazil & $\mathrm{NO}$ & leaves & 0.40 & 25.1 & 196 & [239] \\
\hline Myrtaceae & Ochrosperma & lineare (C.T. White) Trudgen & Australia & $\mathrm{NO}$ & aerial parts & 0.30 & 11.6 & 202 & [240] \\
\hline Myrtaceae & Plinia & edulis (Vell.) Sobral & Brazil & $\mathrm{NO}$ & leaves & 0.10 & 21.2 & 235 & [241] \\
\hline Myrtaceae & Psidium & striatulum $\mathrm{DC}$. & Brazil & NO & leaves & 0.10 & 28.6 & 243 & [242] \\
\hline Myrtaceae & Syzygium & aromaticum $\mathrm{L}$. & Morocco & YES & buds & 8.58 & 27.5 & 270 & [243] \\
\hline Myrtaceae & Syzygium & grande (Wight) Walp. & Vietnam & $\mathrm{NO}$ & stem & 0.12 & 29.3 & 271 & [244] \\
\hline Myrtaceae & Uromyrtus & australis A.J. Scott & Australia & $\mathrm{NO}$ & leaves & 0.12 & 20.7 & 283 & [245] \\
\hline Papilionaceae & Meristotropis & xanthioides Vassilez & Iran & $\mathrm{NO}$ & aerial parts & 3.20 & 11.8 & 184 & [246] \\
\hline Phyllanthaceae & Actephila & excelsa (Dazl.) Muell. & Vietnam & $\mathrm{NO}$ & leaves & 0.15 & 11.2 & 7 & [247] \\
\hline Pinaceae & Abies & nephrolepis (Khingan fir) & South Korea & $\mathrm{NO}$ & needles & 0.40 & 10.8 & 1 & [248] \\
\hline Pinaceae & Pinus & pinaster Aiton & Morocco & YES & needles & 0.38 & 22.2 & 225 & [249] \\
\hline Pinaceae & Pinus & armandii Franch. & Scotland & $\mathrm{NO}$ & needles & n.a. & 36.3 & 226 & [250] \\
\hline Pinaceae & Pinus & bungeana Zucc. & South Korea & $\mathrm{NO}$ & needles & 0.31 & 27.2 & 227 & [251] \\
\hline Pinaceae & Pinus & halepensis Mill. & Turkey & $\mathrm{NO}$ & needles & n.a. & 25.9 & 228 & [252] \\
\hline Piperaceae & Piper & $\begin{array}{l}\text { tuberculatum var. tuberculatum } \\
\text { (Micq.) CDC }\end{array}$ & Brazil & $\mathrm{NO}$ & leaves & n.a. & 26.3 & 229 & [253] \\
\hline Piperaceae & Piper & $\begin{array}{l}\text { guineense Schumach. and } \\
\text { Thonn. }\end{array}$ & Cameroon & $\mathrm{NO}$ & seeds & 1.1 & 57.6 & 230 & [254] \\
\hline Piperaceae & Piper & nigrum $\mathrm{L}$. & India & YES & seeds & n.a. & 45.3 & 231 & [255] \\
\hline
\end{tabular}


Table 1. Cont

\begin{tabular}{|c|c|c|c|c|c|c|c|c|c|}
\hline Family & Genus & Species and Auth & Geogr. Origin of Sample & Belfrit List & Part Used & E.O. Yield \% & ВСР\% & Code & Ref. \\
\hline Piperaceae & Piper & maingayi $\mathrm{Hk}$. F. & Malaysia & $\mathrm{NO}$ & seeds & 0.21 & 39.6 & 232 & [256] \\
\hline Piperaceae & Pothomorphe & peltata (L.) Miq. & Brazil & $\mathrm{NO}$ & leaves & 0.20 & 68.0 & 239 & {$[257]$} \\
\hline Plantaginaceae & Adenosma & indianum (Lour.) Merr. & China & $\mathrm{NO}$ & aerial parts & 0.29 & 10.32 & 8 & [258] \\
\hline Podocarpaceae & Afrocarpus & mannii (Hook.f.) C.N.Page & S. Tomé e Principe & $\mathrm{NO}$ & leaves & 0.15 & 13.1 & 12 & [259] \\
\hline Ptaeroxylaceae & Cedrelopsis & grevei H. Baillon & Madagascar & $\mathrm{NO}$ & barks & n.a. & 10.6 & 71 & {$[260]$} \\
\hline Rosaceae & Agrimonia & eupatoria L. & Iran & YES & flowers & 1.20 & 42.8 & 16 & [261] \\
\hline Rosaceae & Rosa & canina $\mathrm{L}$. & Tunisia & YES & flowers & 1.40 & 32.0 & 250 & {$[262]$} \\
\hline Rubiaceae & Cruciata & laevipes Opiz & Italy & YES & aerial parts & 0.70 & 19.0 & 97 & [263] \\
\hline Rubiaceae & Geophila & repens (L.) I.M. Johnst & China & NO & aerial parts & 0.07 & 23.3 & 129 & [264] \\
\hline Rutaceae & Aegle & marmelos (L.) Corr. & Nepal & YES & leaves & 0.29 & 29.6 & 10 & {$[265]$} \\
\hline Rutaceae & Amyris & elimifera $\mathrm{L}$. & Cuba & NO & leaves & 0.60 & 37.8 & 28 & [266] \\
\hline Rutaceae & Atalantia & buxifolia (Poir.) Oliv. & China & $\mathrm{NO}$ & leaves & 0.36 & 25.8 & 47 & [267] \\
\hline Rutaceae & Boenninghausenia & albiflora Reichb. & India & $\mathrm{NO}$ & flowers & 0.20 & 13.1 & 56 & {$[268]$} \\
\hline Rutaceae & Citrus & garrawayi F.M.Bailey & Australia & $\mathrm{NO}$ & leaves & 0.20 & 17.6 & 80 & [269] \\
\hline Rutaceae & Feroniella & lucida (Scheff.) Swing & Thailand & NO & leaves & 0.12 & 26.6 & 122 & {$[270]$} \\
\hline Rutaceae & Flindersia & pimenteliana F.Muell. & Australia & $\mathrm{NO}$ & leaves & 0.03 & 16.9 & 126 & {$[271]$} \\
\hline Rutaceae & Haplophyllum & villosum (M. B.) G. Don & Iran & $\mathrm{NO}$ & aerial parts & 0.22 & 13.1 & 139 & [272] \\
\hline Rutaceae & Medicosma & obovata T.G. Hartley & Australia & $\mathrm{NO}$ & aerial parts & 0.40 & 17.2 & 177 & [273] \\
\hline Rutaceae & Melicope & peninsularis T.G. Hartley & Australia & $\mathrm{NO}$ & leaves & 0.10 & 49.0 & 179 & [274] \\
\hline Rutaceae & Murraya & paniculata $\mathrm{L}$. & Brazil & $\mathrm{NO}$ & leaves & 0.03 & 57.6 & 192 & [275] \\
\hline Rutaceae & Murraya & koenigii (L.) Spreng & India & YES & leaves & 0.1 & 45.9 & 193 & {$[276]$} \\
\hline Rutaceae & Pamburus & missionis (Wight) Swingle & India & NO & leaves & 0.05 & 25.4 & 213 & [277] \\
\hline Rutaceae & Spiranthera & odoratissima A. St. Hil. & Brazil & $\mathrm{NO}$ & leaves & n.a. & 23.8 & 267 & [278] \\
\hline Rutaceae & Zanthoxylum & veneficum F.M.Bailey & Australia & $\mathrm{NO}$ & leaves & 0.10 & 36.3 & 292 & [279] \\
\hline Sapindaceae & Acer & truncatum Bunge & China & $\mathrm{NO}$ & leaves & n.a. & 12.9 & 3 & [280] \\
\hline Schisandraceae & Kadsura & coccinea (Lem.) A.C. Smith & China & $\mathrm{NO}$ & roots & 0.20 & 24.9 & 157 & [281] \\
\hline Scrophulariaceae & Buddleia & asiatica Lour. & India & $\mathrm{NO}$ & leaves & 0.30 & 15.8 & 58 & [282] \\
\hline Scrophulariaceae & Capraria & biflora $\mathrm{L}$ & Brazil & $\mathrm{NO}$ & leaves & 0.09 & 29.6 & 66 & [283] \\
\hline Solanaceae & Solanum & stipulaceum Roem and Schult & Brazil & $\mathrm{NO}$ & flowers & 0.08 & 25.8 & 265 & [284] \\
\hline Verbenaceae & Aloysia & virgata Juss. & Cuba & $\mathrm{NO}$ & aerial parts & n.a. & 15.4 & 22 & [285] \\
\hline Verbenaceae & Lantana & montevidensis Briq & Brazil & $\mathrm{NO}$ & leaves & 0.13 & 31.5 & 163 & [286] \\
\hline Verbenaceae & Lantana & camara $\mathrm{L}$. & Madagascar & $\mathrm{NO}$ & aerial parts & 0.08 & 43.61 & 164 & [287] \\
\hline
\end{tabular}


Table 1. Cont.

\begin{tabular}{|c|c|c|c|c|c|c|c|c|c|}
\hline Family & Genus & Species and Auth & Geogr. Origin of Sample & Belfrit List & Part Used & E.O. Yield \% & ВСР\% & Code & Ref. \\
\hline Verbenaceae & Lippia & $\begin{array}{l}\text { myriocephala Schltdl. et } \\
\text { Cham. }\end{array}$ & Costa Rica & $\mathrm{NO}$ & leaves & 0.08 & 16.1 & 171 & [288] \\
\hline Verbenaceae & Petitia & domingensis Jacq. & Cuba & $\mathrm{NO}$ & flowers & n.a. & 35.7 & 219 & [289] \\
\hline Zingiberaceae & Aframomum & $\begin{array}{l}\text { corrorima (Braun) P.C.M. } \\
\text { Jansen }\end{array}$ & Ethiopia & $\mathrm{NO}$ & leaves & 0.50 & 60.7 & 11 & [290] \\
\hline Zingiberaceae & Alpinia & purpurata (Viell.) & Fiji & $\mathrm{NO}$ & flowers & 0.05 & 24.2 & 23 & [291] \\
\hline Zingiberaceae & Alpinia & conchigera Griff. & Malaysia & $\mathrm{NO}$ & rhizomes & 0.14 & 10.0 & 24 & [292] \\
\hline Zingiberaceae & Alpinia & mutica Roxb. & Vietnam & $\mathrm{NO}$ & fruit & 0.17 & 22.6 & 25 & [293] \\
\hline Zingiberaceae & Alpinia & $\begin{array}{l}\text { pinnanensis } \mathrm{T} . \mathrm{L} . \mathrm{Wu} \text { and } \\
\text { Senjen }\end{array}$ & Vietnam & $\mathrm{NO}$ & fruit & 0.23 & 11.4 & 26 & [294] \\
\hline Zingiberaceae & Costus & afer Ker-Grawl & Nigeria & $\mathrm{NO}$ & leaves & n.a. & 12.3 & 93 & [295] \\
\hline Zingiberaceae & Curcuma & longa $\mathrm{L}$. & India & YES & rhizomes & 2.20 & 9.8 & 99 & [296] \\
\hline Zingiberaceae & Etlingera & elatior (Jack) R. M. Smith & Malaysia & $\mathrm{NO}$ & leaves & 0.70 & 10.7 & 117 & [297] \\
\hline Zingiberaceae & Globba & schomburgkii Hook. f. & India & $\mathrm{NO}$ & aerial parts & 0.01 & 31.7 & 133 & [298] \\
\hline Zingiberaceae & Hedychium & coronarium Koen. & Brazil & YES & leaves & 0.68 & 43.0 & 140 & [299] \\
\hline Zingiberaceae & Renealmia & breviscapa Poepp. and Endl. & Brazil & $\mathrm{NO}$ & rhizomes & 0.01 & 62.3 & 247 & [300] \\
\hline Zingiberaceae & Renealmia & alpinia (Rottb.) Maas & Brazil & $\mathrm{NO}$ & leaves & 0.50 & 22.9 & 248 & [301] \\
\hline Zingiberaceae & Zingiber & nimmonii Dalzell & India & $\mathrm{NO}$ & rhizomes & 0.04 & 42.2 & 293 & [302] \\
\hline
\end{tabular}


The essential oil yield of 243 species ranged from 0.001 to $8.58 \%$, whereas the $\mathrm{BCP}$ percentage of all selected species ranged from 9.8 (the threshold minimum level for species selection) to $75.6 \%$ (Table 2), providing an average percentage of $0.42 \%$ for yield and $27.4 \%$ for BCP. As shown in Table 2, variability was higher for yield percentages than for $\mathrm{BCP}$ percentage. The reason for the yield and $\mathrm{BCP}$ variability depends on several factors, including plant part, the quantity of plant material distilled and, most of all, the genetic variability and phenotypic plasticity of plants [303-306].

Table 2. General statistics on BCP and yield percentages of plant species listed in Table 1.

\begin{tabular}{lcc}
\hline \multicolumn{1}{c}{ Specification } & Essential Oil Yield & Percentage of BCP \\
\hline Number of cases & 243 & 295 \\
Range & & \\
Minimum & 0.00 & 9.8 \\
Maximum & 8.58 & 75.6 \\
Mean & 0.42 & 27.4 \\
S.E.M. & 0.06 & 0.8 \\
S.D. & 0.87 & 13.6 \\
C.V. \% & 2.09 & 0.5 \\
\hline S.E.M standard error of the mean; S.D. standard deviation; C. V coefficient of variation.
\end{tabular}

In order to look for plant species with the highest $\mathrm{BCP}$ and yield percentages, a scatter plot was obtained, as depicted in Figure 1. The highest yield and BCP percentages were found for Copaifera langsdorffii. High BCP percentages but with decreasing yields were found for Bursera microphylla, Scutellaria havanensis and Pentadesma butyracea. Copaifera species, popularly known as copaiba oil, are widely used in Brazilian popular medicine and the genus is known for its high essential oil yield and BCP content $[135,307,308]$. The genus Bursera belongs to the plant family Burseraceae and contains several aromatic spices producing oleo-gum resins, such as the traditional incenses, frankincense and myrrh [309]. Pentadesma butyracea (Clusiaceae) is a dense forest species which is found in the center and north of Benin forests whose bark, rough and deeply cracked, exudes a thick resinous juice, of reddish yellow color [115]. The Scutellaria genus (Lamiaceae) consists of plants which are widely distributed throughout the world; S. butyracea is an endemic plant native from Havana and is ethnomedically used for several purposes because of its BCP content [196].

High yields with lower BCP percentages were found for Acalypha fruticosa, Achyrocline alata, Agrimonia eupatoria, Bowdichia virgilioides, Bursera microphylla, Croton pulegiodorus, Curcuma longa, Glechon marifolia, Laser trilobum, Meristotropis xanthioides, Origanum majorana, Pimpinella kotschyana, Piper guineense, Rosa canina, Salvia canariensis, Spondias pinnata, Syzygium aromaticum and Thuja orientalis. All other species had a yield ranging from 0.004 to $1 \%$ and a BCP content ranging from 9.8 to $55 \%$ (Figure 1 ).

The plant part that contained the highest content of $\mathrm{BCP}$ was then analyzed. In order to evidence the statistical linkage between the plant parts, a cluster analysis was calculated by considering as category the plant part and as variables the number of species, the $\mathrm{BCP} \%$ and the yield $\%$ reported in Table 1 (Figure 2). Euclidean distances were calculated by using the average linkage method. Five clusters were evidenced: the first cluster was made by plant parts reported in more than 100 species and was dominated by leaves and aerial parts, which contained in general a BCP percentage lower than $28 \%$. The other four clusters were made by plant parts reported in less than 16 species. These four clusters were further subdivided according to their BCP content (Figure 2). As expected, the highest $\mathrm{BCP}$ percentage was found in oleo-gum resins (cluster 2), followed by roots, barks and branches (cluster 3). Flowers and buds (cluster 4) showed a high yield, whereas twigs and woods (cluster 5) had both low yields and BCP percentages (Figure 2). 


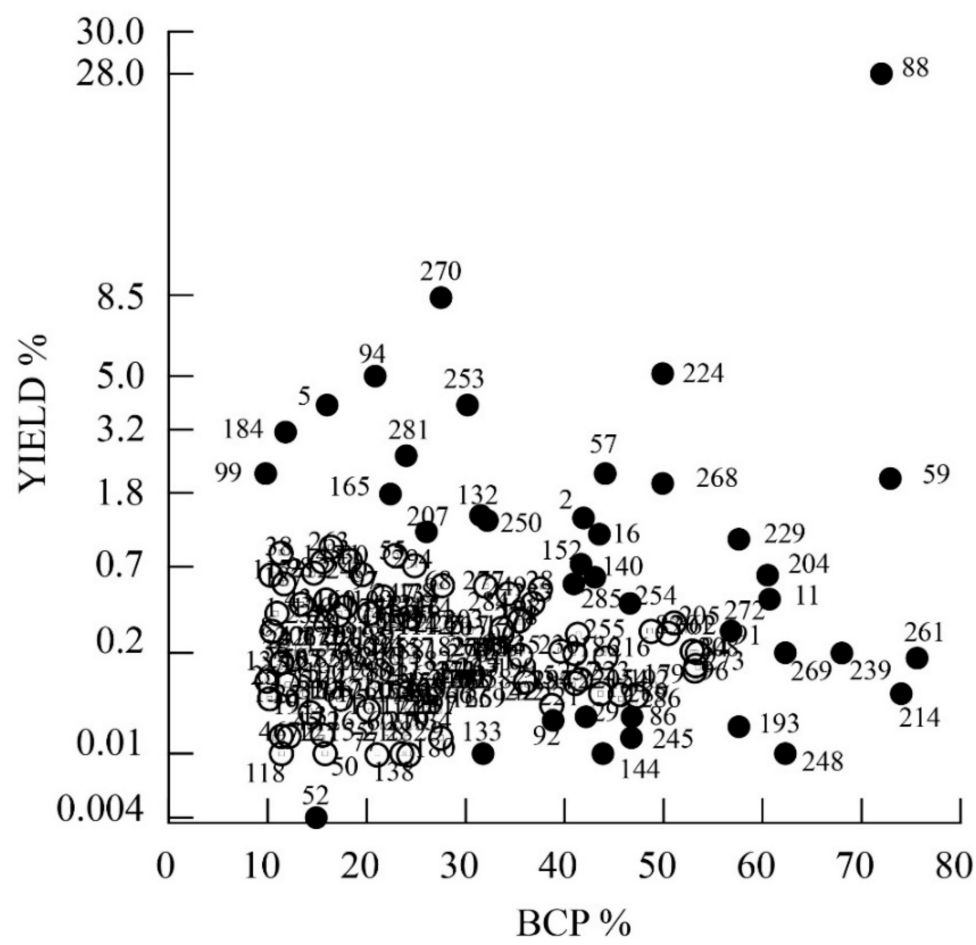

Figure 1. Scatter plot of $\mathrm{BCP}$ percentage vs. yield percentage. The yield axis is represented as a power of 0.3 scale in order to evidence species with yields ranging from 0.004 to $3 \%$. Numbers correspond to plant species listed in Table 1. Filled circles outline the species outside the central group of all other species (hollow circles).

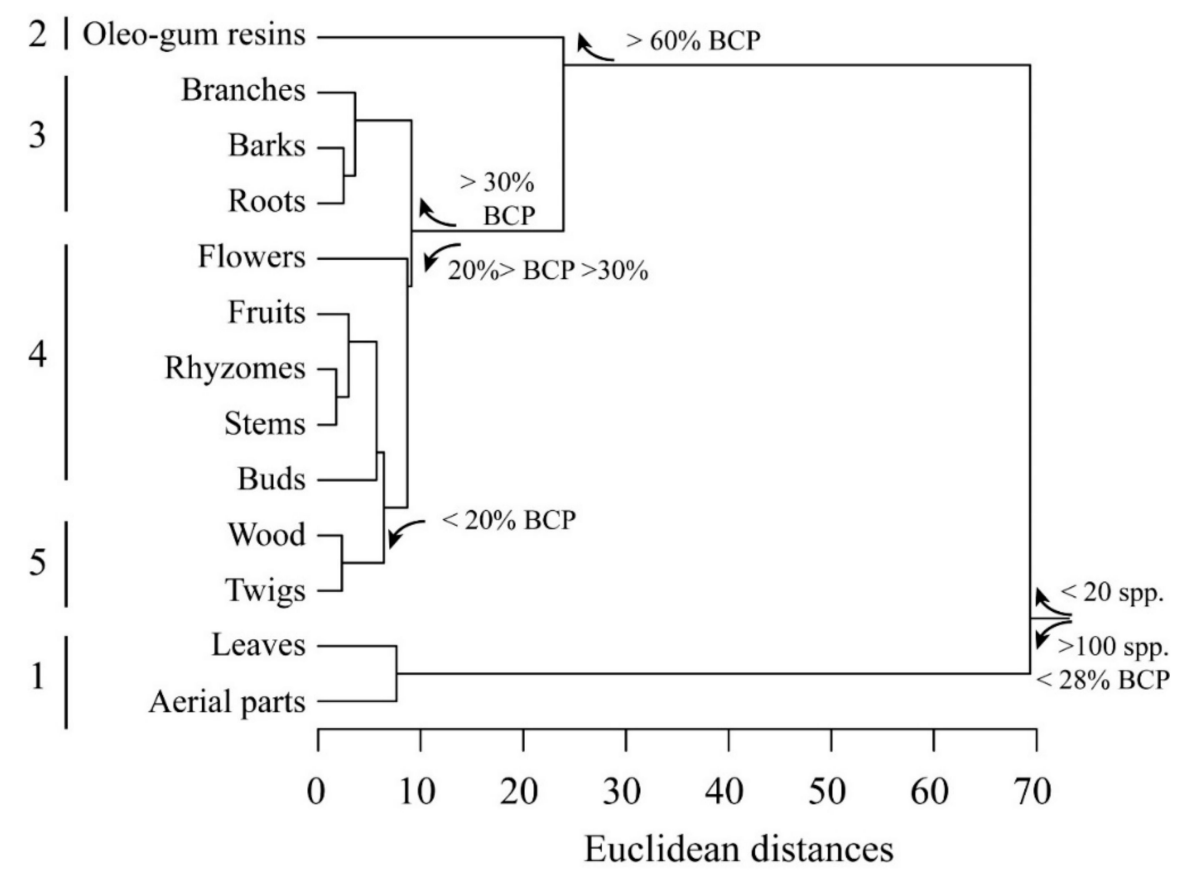

Figure 2. Cluster analysis of BCP and yield percentages according to the plant part used for extraction. Euclidean distances are calculated with average linkage method. Five clusters are evident (see text for explanation).

Table 3 summarizes the statistical analysis of $\mathrm{BCP}$ and yield percentages reported from different plant parts. 
Table 3. Average percentages of BCP and yields from plant parts as reported in plant species listed in Table 1. ( \pm S.E.M.); n.c., not computable; E.O., essential oil.

\begin{tabular}{cccc}
\hline Plant Part & $\begin{array}{c}\text { Number of } \\
\text { Species }\end{array}$ & BCP \% & E.O. Yield \% \\
\hline Aerial Parts & 115 & $25.19( \pm 1.10)$ & $0.42( \pm 4.85)$ \\
Barks & 3 & $39.03( \pm 18.59)$ & $0.30( \pm 0.22)$ \\
Branches & 1 & $34.90( \pm$ n.c. $)$ & $0.20( \pm$ n.c. $)$ \\
Buds & 1 & $27.50( \pm$ n.c. $)$ & $8.58( \pm$ n.c. $)$ \\
Flowers & 16 & $29.29( \pm 3.11)$ & $0.41( \pm 0.13)$ \\
Fruits & 9 & $26.93( \pm 4.43)$ & $0.24( \pm 0.07)$ \\
Leaves & 128 & $27.58( \pm 1.15)$ & $0.30( \pm 0.04)$ \\
Oleo-gum resin & 4 & $66.13( \pm 4.54)$ & $15.50( \pm 8.30)$ \\
Rhyzomes & 5 & $27.38( \pm 10.65)$ & $0.49( \pm 0.43)$ \\
Roots & 7 & $39.77( \pm 5.37)$ & $1.77( \pm 0.92)$ \\
Stems & 3 & $25.07( \pm 7.66)$ & $0.13( \pm 0.04)$ \\
Twigs & 2 & $16.25( \pm 4.85)$ & $0.02( \pm 0.01)$ \\
Wood & 1 & $19.40( \pm$ n.c. $)$ & $0.42( \pm$ n.c. $)$ \\
\hline
\end{tabular}

The next analysis was at the familial level. A cluster analysis was calculated with average linkage method by using data of Table 1 by considering as a category the plant families and the species number, yield \% and $\mathrm{BCP} \%$ as variables. The results of the cluster analysis show the presence of 6 clusters (Figure 3). The first cluster is made by the Asteraceae and the Lamiaceae which consist of a number of species $>50$ and a $\mathrm{BCP} \%<31$. The second cluster gathers all families whose species have a $\mathrm{BCP} \%>35 \%$; in this cluster, the Magnoliaceae and the Papilionaceae are separated in a subcluster because of their high $\mathrm{BCP} \%$ and low yield $\%$, whereas the Fabaceae (which include the above mentioned C. langsdorffii) are separated in a subcluster because of their high yield \%. The third cluster is made by families with a number of species $>13$ and a $\mathrm{BCP} \%>23 \%$; here, the Lauraceae, the Apiaceae and the Zingiberaceae are separated in a subcluster because of their higher $\mathrm{BCP} \%$. The genus Ocotea is one of the largest of the Lauraceae family, with approximately 350 species distributed throughout tropical and subtropical America. O. splendens, as many other Ocotea species [212] is characterized by a high percentage of BCP [217]. In the Apiaceae family, the species P. kotschyana spreads widely through Anatoly, Iran (northwest, west and center) and north of Iraq and contains BCP in all plant parts [41]. The family Zingiberaceae is well known for producing essential oils that are used to prevent and control several diseases; the species $R$. breviscapa was found to possess a high percentage of $\mathrm{BCP}$ [300]. The fourth cluster is made by families with a $\mathrm{BCP} \%>26$ and a subcluster separates the Atherospermaceae, the Flacourtiaceae and the Meliaceae because of their $\mathrm{BCP} \%$. The fifth cluster is made by families with a $\mathrm{BCP} \%<25$ and the Plantaginaceae are separated in a subcluster because of their relatively higher yield\%. Finally, the sixth cluster is made by plant families with a low BCP percentage and a subcluster separates the Hernandiaceae, the Juglandaceae, the Phyllanthace and the Ptaeroxylaceae because of their BCP content lower than $11 \%$. 


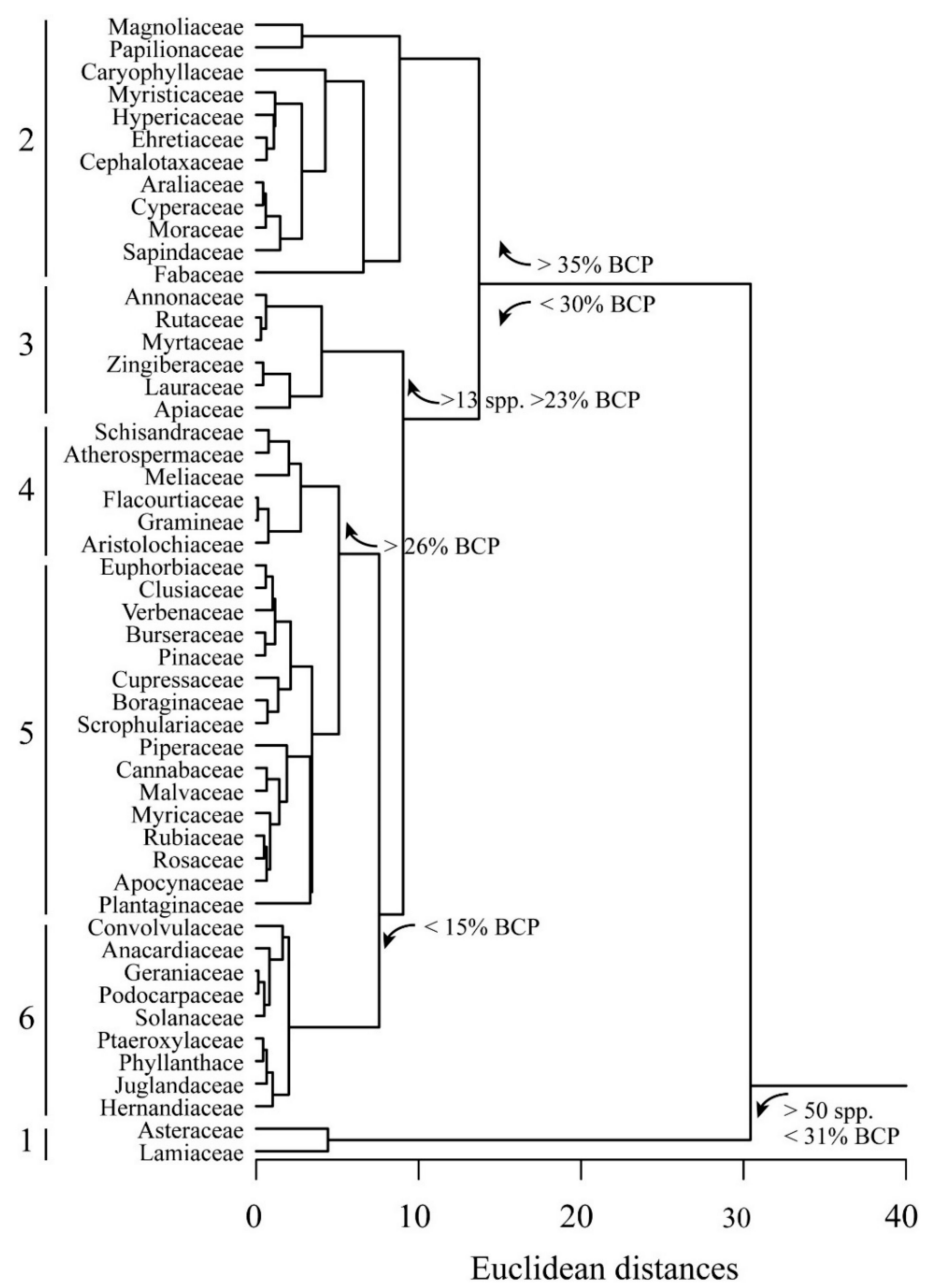

Figure 3. Cluster analysis of BCP and yield percentages according to the plant families. Euclidean distances are calculated with average linkage method. Six clusters are evident (see text for explanation).

Table 4 describes the statistical data related to plant families.

The next analysis aimed to evidence the geographical areas from which the plant species listed in Table 1 were collected. A cluster analysis was calculated with average linkage method, considering the country of origin as a category of their species number, yield $\%$ and $\mathrm{BCP} \%$ as variables. The results of the cluster analysis show the presence of 6 clusters (Figure 4). The first cluster gathers countries with the highest number of species and a BCP percentage higher than $28 \%$; here, a subcluster separates Brazil from India and Iran because of the higher number of species, in agreement with the literature data [310]. The second and third clusters identify countries where $\mathrm{BCP}$ has the highest percentages, whereas the fourth cluster gathers countries with a number of species higher than 8 . The fifth cluster is made by countries where the BCP content is the lowest, whereas the sixth cluster is made by two subclusters with $\mathrm{BCP}$ percentages ranging from 18 to $25 \%$. One of these subclusters is made by countries (Colombia, Fiji, Kenya, Morocco, Niger, North Korea, Portugal and Togo) where the species had a BCP percentage higher than $24 \%$ (Figure 4 ). 
Table 4. Average percentages of BCP and yields from plant families belonging to the plant species reported in Table 1. ( \pm S.E.M.); n.c., not computable; n.a., not available; E.O., essential oil.

\begin{tabular}{|c|c|c|c|}
\hline Family & Number of Species & ВСР\% & E.O. Yield\% \\
\hline Anacardiaceae & 2 & $13.25( \pm 2.65)$ & n.a. \\
\hline Annonaceae & 15 & $22.17( \pm 1.26)$ & $0.20( \pm 0.05)$ \\
\hline Apiaceae & 16 & $30.96( \pm 4.15)$ & $0.37( \pm 0.14)$ \\
\hline Apocynaceae & 3 & $17.63( \pm 3.05)$ & $0.26( \pm 0.10)$ \\
\hline Araliaceae & 1 & 39.00 (n.c.) & 0.04 (n.c.) \\
\hline Aristolochiaceae & 2 & $26.65( \pm 3.75)$ & $0.21( \pm 0.13)$ \\
\hline Asteraceae & 50 & $27.94( \pm 1.92)$ & $0.47( \pm 0.14)$ \\
\hline Atherospermaceae & 1 & 32.20 (n.c.) & 0.06 (n.c.) \\
\hline Boraginaceae & 2 & $22.95( \pm 10.15)$ & $0.15( \pm 0.10)$ \\
\hline Burseraceae & 5 & $24.20( \pm 4.83)$ & $0.14( \pm 0.02)$ \\
\hline Cannabaceae & 3 & $20.24( \pm 5.14)$ & $0.27( \pm 0.14)$ \\
\hline Caryophyllaceae & 1 & 46.60 (n.c.) & 0.48 (n.c.) \\
\hline Cephalotaxaceae & 1 & 41.60 (n.c.) & 0.82 (n.c.) \\
\hline Clusiaceae & 5 & $25.85( \pm 6.84)$ & $0.29( \pm 0.19)$ \\
\hline Convolvulaceae & 1 & 15.10 (n.c.) & n.a. \\
\hline Cupressaceae & 3 & $23.83( \pm 9.60)$ & $1.59( \pm 0.84)$ \\
\hline Cyperaceae & 1 & 38.40 (n.c.) & n.a. \\
\hline Ehretiaceae & 2 & $41.95( \pm 15.65)$ & 1.10 (n.c.) \\
\hline Euphorbiaceae & 6 & $25.60( \pm 15.42)$ & $0.42( \pm 0.46)$ \\
\hline Fabaceae & 11 & $36.92( \pm 6.15)$ & $3.89( \pm 3.45)$ \\
\hline Flacourtiaceae & 2 & $27.75( \pm 3.15)$ & n.a. \\
\hline Geraniaceae & 1 & 13.10 (n.c.) & 0.22 (n.c.) \\
\hline Gramineae & 2 & $27.90( \pm 13.50)$ & $0.19( \pm 0.09)$ \\
\hline Hernandiaceae & 1 & 9.80 (n.c.) & 2.20 (n.c.) \\
\hline Hypericaceae & 3 & $41.10( \pm 15.86)$ & $0.13( \pm 0.05)$ \\
\hline Juglandaceae & 1 & 10.00 (n.c.) & 0.15 (n.c.) \\
\hline Lamiaceae & 57 & $31.03( \pm 2.03)$ & $0.41( \pm 0.17)$ \\
\hline Lauraceae & 13 & $29.33( \pm 3.14)$ & $0.38( \pm 0.18)$ \\
\hline Magnoliaceae & 1 & 56.90 (n.c.) & 0.30 (n.c.) \\
\hline Malvaceae & 2 & $19.70( \pm 5.20)$ & $0.11( \pm 0.04)$ \\
\hline Meliaceae & 4 & $30.55( \pm 9.27)$ & $0.14( \pm 0.03)$ \\
\hline Moraceae & 1 & 37.80 (n.c.) & 0.60 (n.c.) \\
\hline Myricaceae & 1 & 18.10 (n.c.) & 0.30 (n.c.) \\
\hline Myristicaceae & 3 & $42.93( \pm 10.61)$ & $1.35( \pm 0.85)$ \\
\hline Myrtaceae & 15 & $23.49( \pm 2.17)$ & $0.27( \pm 0.08)$ \\
\hline Papilionaceae & 1 & 52.00 (n.c.) & 0.30 (n.c.) \\
\hline Phyllanthace & 1 & 10.70 (n.c.) & n.a. \\
\hline Pinaceae & 5 & $23.22( \pm 5.33)$ & $0.20( \pm 0.06)$ \\
\hline Piperaceae & 5 & $19.70( \pm 2.26)$ & $0.23( \pm 0.07)$ \\
\hline Plantaginaceae & 1 & 20.90 (n.c.) & 5.00 (n.c.) \\
\hline Podocarpaceae & 1 & 12.90 (n.c.) & n.a. \\
\hline Ptaeroxylaceae & 1 & 11.30 (n.c.) & 0.72 (n.c.) \\
\hline Rosaceae & 2 & $18.00( \pm 6.60)$ & $0.10( \pm 0.08)$ \\
\hline Rubiaceae & 2 & $17.15( \pm 0.25)$ & 0.03 (n.c.) \\
\hline Rutaceae & 15 & $22.97( \pm 2.69)$ & $0.27( \pm 0.06)$ \\
\hline Sapindaceae & 1 & 36.30 (n.c.) & n.a. \\
\hline Schisandraceae & 1 & 32.00 (n.c.) & 1.40 (n.c.) \\
\hline Scrophulariaceae & 2 & $21.75( \pm 0.65)$ & 0.10 (n.c.) \\
\hline Solanaceae & 1 & 12.20 (n.c.) & 0.20 (n.c.) \\
\hline Verbenaceae & 5 & $24.70( \pm 6.58)$ & $1.59( \pm 1.20)$ \\
\hline Zingiberaceae & 13 & $28.61( \pm 4.25)$ & $0.22( \pm 0.06)$ \\
\hline
\end{tabular}




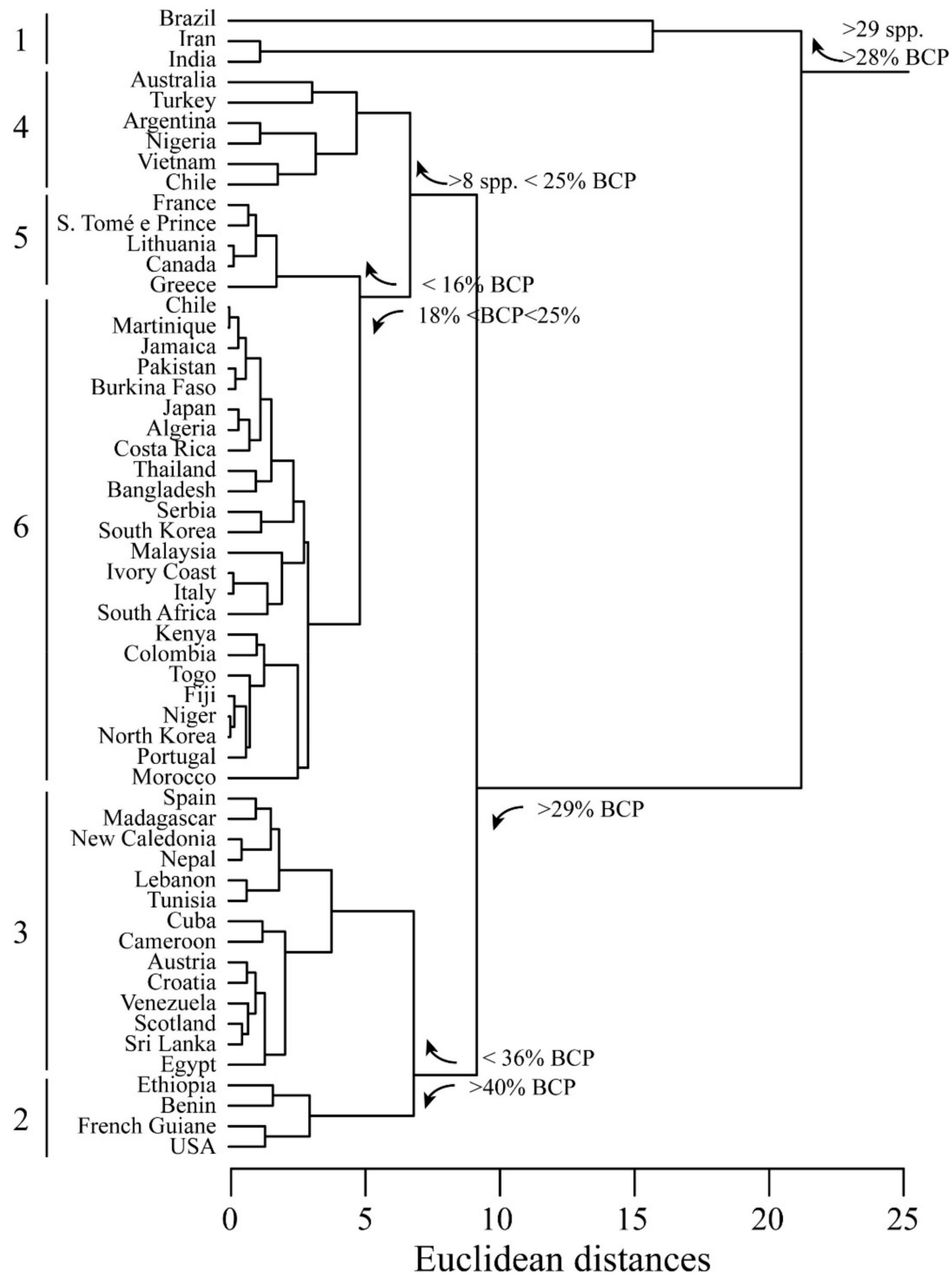

Figure 4. Cluster analysis of BCP and yield percentages according to the country of origin of extracts. Euclidean distances are calculated with average linkage method. Six clusters are evident (see text for explanation).

Table 5 summarizes the statistics related to countries of origin. 
Table 5. Average percentages of BCP and yields from countries from which plant species reported in Table 1 were sampled. ( \pm S.E.M.); n.c., not computable; n.a., not available; E.O., essential oil.

\begin{tabular}{|c|c|c|c|}
\hline Country & Number of Species & ВСР\% & E.O. Yield \% \\
\hline Algeria & 3 & $20.67( \pm 4.65)$ & $0.61( \pm 0.59)$ \\
\hline Argentina & 8 & $25.85( \pm 5.41)$ & $0.19( \pm 0.07)$ \\
\hline Australia & 18 & $25.70( \pm 2.98)$ & $0.18( \pm 0.04)$ \\
\hline Austria & 2 & $34.85( \pm 18.65)$ & 0.15 (n.c.) \\
\hline Bangladesh & 1 & 19.40 (n.c.) & n.a. \\
\hline Benin & 3 & $43.77( \pm 17.44)$ & $0.09( \pm 0.01)$ \\
\hline Brazil & 56 & $33.01( \pm 2.20)$ & $1.08( \pm 0.59)$ \\
\hline Burkina Faso & 2 & $21.65( \pm 2.55)$ & $0.38( \pm 0.36)$ \\
\hline Cameroon & 4 & $34.40( \pm 8.12)$ & $0.56( \pm 0.30)$ \\
\hline Canada & 1 & 14.50 (n.c.) & 0.15 (n.c.) \\
\hline Chile & 1 & 21.10 (n.c.) & 0.15 (n.c.) \\
\hline China & 11 & $19.26( \pm 2.54)$ & $0.18( \pm 0.04)$ \\
\hline Colombia & 2 & $26.45( \pm 5.75)$ & $0.11( \pm 0.05)$ \\
\hline Costa Rica & 3 & $19.53( \pm 5.61)$ & $0.16( \pm 0.07)$ \\
\hline Croatia & 1 & 35.40 (n.c.) & 0.35 (n.c.) \\
\hline Cuba & 5 & $36.30( \pm 10.85)$ & $0.41( \pm 0.12)$ \\
\hline Egypt & 2 & $36.95( \pm 12.95)$ & $2.30( \pm 0.30)$ \\
\hline Ethiopia & 2 & $41.15( \pm 19.55)$ & $0.32( \pm 0.19)$ \\
\hline Fiji & 1 & 24.20 (n.c.) & 0.05 (n.c.) \\
\hline France & 2 & $12.35( \pm 0.35)$ & $0.15( \pm 0.05)$ \\
\hline French Guian & 1 & 47.00 (n.c.) & 0.06 (n.c.) \\
\hline Greece & 1 & 16.40 (n.c.) & 1.00 (n.c.) \\
\hline India & 29 & $27.00( \pm 2.32)$ & $0.34( \pm 0.11)$ \\
\hline Iran & 30 & $28.69( \pm 2.02)$ & $0.67( \pm 0.22)$ \\
\hline Italy & 5 & $22.54( \pm 2.55)$ & $0.26( \pm 0.12)$ \\
\hline Ivory Coast & 5 & $22.24( \pm 3.48)$ & $0.25( \pm 0.13)$ \\
\hline Jamaica & 1 & 21.70 (n.c.) & 0.03 (n.c.) \\
\hline Japan & 3 & $20.93( \pm 1.94)$ & $0.05( \pm 0.02)$ \\
\hline Kenya & 3 & $24.97( \pm 2.94)$ & $0.17( \pm 0.12)$ \\
\hline Lebanon & 2 & $31.55( \pm 18.65)$ & $0.20( \pm 0.11)$ \\
\hline Lithuania & 1 & 14.20 (n.c.) & 0.05 (n.c.) \\
\hline Madagascar & 3 & $29.10( \pm 9.74)$ & $0.14( \pm 0.06)$ \\
\hline Malaysia & 7 & $20.56( \pm 3.98)$ & $0.25( \pm 0.11)$ \\
\hline Martinique & 1 & 21.10 (n.c.) & 0.11 (n.c.) \\
\hline Morocco & 2 & $24.85( \pm 2.65)$ & $4.48( \pm 4.10)$ \\
\hline Nepal & 1 & 29.60 (n.c.) & 0.29 (n.c.) \\
\hline New Caledonia & 1 & 28.80 (n.c.) & 0.10 (n.c.) \\
\hline Niger & 1 & 24.00 (n.c.) & 0.30 (n.c.) \\
\hline Nigeria & 10 & $25.87( \pm 4.39)$ & $0.19( \pm 0.09)$ \\
\hline North Korea & 1 & 24.00 (n.c.) & 0.40 (n.c.) \\
\hline Pakistan & 2 & $21.40( \pm 3.90)$ & 0.03 (n.c.) \\
\hline Portugal & 2 & $23.65( \pm 0.95)$ & $0.26( \pm 0.09)$ \\
\hline S. Tomé e Prince & 1 & 13.10 (n.c.) & 0.15 (n.c.) \\
\hline Scotland & 1 & 36.30 (n.c.) & n.a. \\
\hline Serbia & 4 & $18.35( \pm 3.47)$ & $0.05( \pm 0.03)$ \\
\hline South Africa & 5 & $24.86( \pm 3.65)$ & $0.09( \pm 0.02)$ \\
\hline South Korea & 4 & $16.30( \pm 3.83)$ & $0.36( \pm 0.05)$ \\
\hline Spain & 4 & $28.23( \pm 4.44)$ & $1.23( \pm 0.93)$ \\
\hline Sri Lanka & 1 & 37.00 (n.c.) & 0.50 (n.c.) \\
\hline Thailand & 2 & $18.40( \pm 8.20)$ & $0.10( \pm 0.03)$ \\
\hline Togo & 1 & 25.20 (n.c.) & 0.50 (n.c.) \\
\hline Tunisia & 3 & $32.00( \pm 5.08)$ & $0.52( \pm 0.44)$ \\
\hline Turkey & 14 & $29.21( \pm 3.51)$ & $0.25( \pm 0.08)$ \\
\hline USA & 2 & $47.45( \pm 25.45)$ & 2.10 (n.c.) \\
\hline Venezuela & 2 & $36.40( \pm 9.30)$ & $0.06( \pm 0.01)$ \\
\hline Vietnam & 11 & $22.38( \pm 4.01)$ & $0.28( \pm 0.08)$ \\
\hline
\end{tabular}


In order to separate which species containing BCP were also represent in the Belfrit list, a scatter plot was obtained by selecting $\mathrm{BCP} \%$ and yield $\%$ as variables (Figure 5). C. langdorffii, S. aromaticum, C. long $a$ and $B$. virgilioides were characterized by a yield ranging from 2 to $28 \%$, with varying percentages of $\mathrm{BCP}$; on the other hand, high percentages of BCP but lower yields $\%$ were found for A. eupatoria, H. coronarium, C. odorata, P. americana and M. keonigi. All other species showed both lower yields and $\mathrm{BCP}$ percentage.

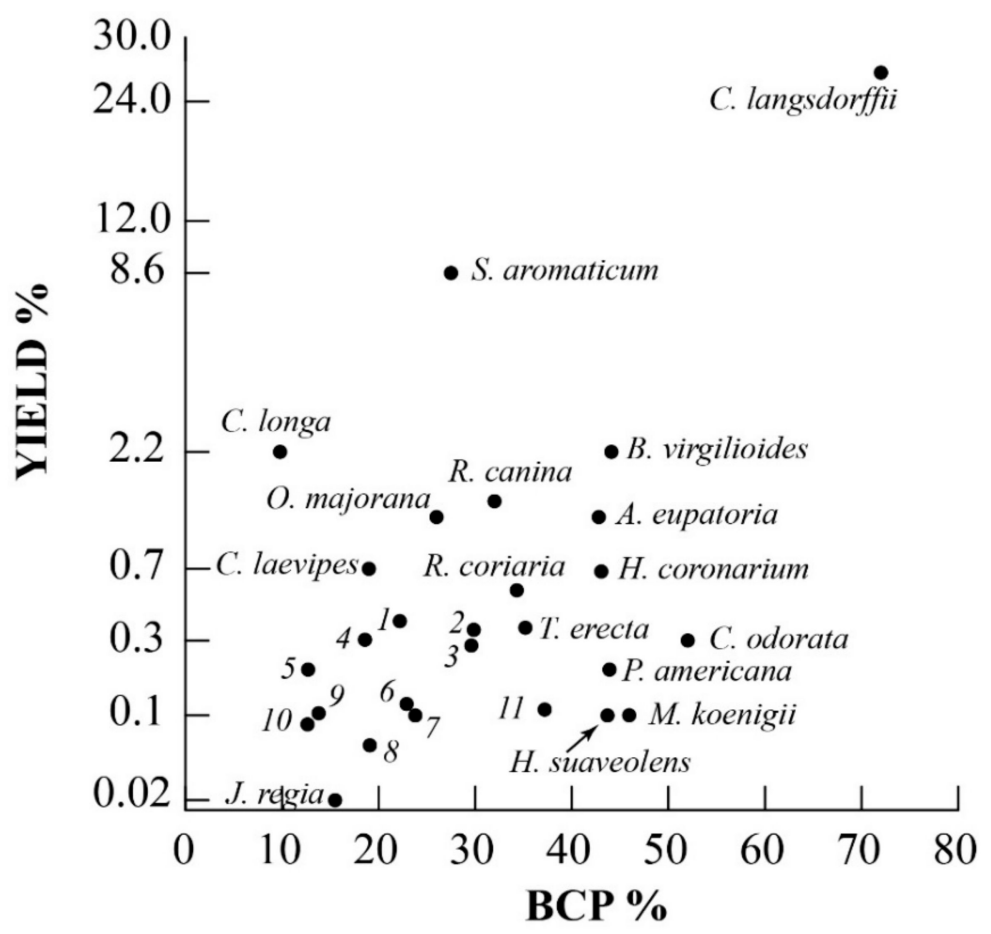

Figure 5. Scatter plot of $\mathrm{BCP} \%$ and yield $\%$ of plant species present in the Belfrit list. The yield axis is scaled as a power of 0.2 in order to evidence species with yields ranging from 0.02 to $8.6 \%$. 1, Pinus pinaster Aiton; 2, Ocimum tenuiflorum L.; 3, Aegle marmelos (L.) Corr.; 4, Protium heptaphyllum (Aubl.) March.; 5, Artemisia verlotiorum Lam rinus officinalis L.; 6, Annona squamosa L.; 7, Cannabis sativa L.; 8, Centella asiatica L.; 9, Annona muricata L.; 10, Rosmarinus officinalis L; 11, Perilla frutescens var. japonica (Hassk.) H. Hara.

\section{Materials and Methods}

\subsection{Systematic Analysis of BCP-Containing Plant Species}

After a preliminary search by using different databases, the work was performed by using Clarivate Analytics Web of Science as a database (http://apps.webofknowledge.com). The basic search criterion was on the general search for the molecule (caryophyllene), then the exclusion criteria were the presence of $\mathrm{BCP}$ and a percentage of $\mathrm{BCP}$ in the reported results higher than $10 \%$. Papers reporting the occurrence of $\mathrm{BCP}$ where then downloaded and saved as a pdf for further reading and collection of information.

\subsection{Statistical Analysis}

The binomial name of the species (including the author), the family of belonging, the plant part used, the country of origin of the sample, the yield and the BCP percentages were inserted in a database by using Systat ${ }^{\circledR} 10$ software (Systat Software Inc., San Jose, California, U.S.A.). Data were organized in columns and used for further processing. Average values along with ranges, standard deviation (S.D.), standard error of the mean (S.E.M.) and coefficient of variation (C.V.) were calculated by considering as grouping categories either the species, families, country of origin or plant part used. 
As a classification statistical method, a cluster analysis was calculated by considering for each category the total number of species, the BCP percentage and the yield percentage by using Systat ${ }^{\circledR} 10$ software. Euclidean distances were calculated with the average linkage method. Data were plotted as either scatter plots of yield percentage vs. BCP percentage or dendrograms showing the different clusters according to the calculated distance.

\section{Conclusions}

The attractiveness of $\mathrm{BCP}$, a natural sesquiterpene present in the essential oil of different plant species, arises from its pharmacological feature as a CB2 receptor agonist. This characteristic, along with the lack of interaction with the $\mathrm{CB} 1$, makes $\mathrm{BCP}$ an interesting plant endocannabinoid with the advantage of lacking any psychotropic effect, as is typical of some Cannabis extracts [8,311,312].

This systematic analysis of published literature on plant species containing BCP in their essential oils identified the species with the highest yield and BCP content and allowed to select which species are also present in the Belfrit list (i.e., potentially attractive for pharmaceutical and nutraceutical industries).

This survey also evidenced the common practice of many authors to ignore the importance of providing the yield of the distilled essential oil, which represent a basic starting point for all industrial applications of the plant species under study. This problem was often correlated with the low amount of plant material distilled. Although interesting from a chemical-analytical point of view, the sole chemical analysis of the essential oil is not useful if performed on a single plant or a few plants, because it does not provide any information on the population genetic variability, being mainly affected by phenotypic plasticity, which is responsible for individual variations inside a population [305].

This work identified some top species like C. langsdforffii, C. odorata, H. lupulus, P. nigrum and S. aromaticum, which provide a high percentage of $\mathrm{BCP}$ along with interesting yields. These species, upon a skillful molecular fractionation to remove undesired/toxic monoterpenes, may provide high percentages of BCP that can be used for the preparation of new drugs or dietary supplements aimed to improve health, prevent lifestyle diseases and act as a valid support for chronical diseases such as pain, metabolic and neurological disorders.

Funding: This research was funded by the University of Turin, local research grant number to M.E.M.

Conflicts of Interest: The author declares no conflict of interest.

\section{Abbreviations}

$\mathrm{BCP}$

(E)- $\beta$-caryophyllene

\section{References}

1. Gertsch, J.; Leonti, M.; Raduner, S.; Racz, I.; Chen, J.-Z.; Xie, X.-Q.; Altmann, K.-H.; Karsak, M.; Zimmer, A. Beta-caryophyllene is a dietary cannabinoid. Proc. Natl. Acad. Sci. USA 2008, 105, 9099-9104. [CrossRef] [PubMed]

2. Francomano, F.; Caruso, A.; Barbarossa, A.; Fazio, A.; La Torre, C.; Ceramella, J.; Mallamaci, R.; Saturnino, C.; Iacopetta, D.; Sinicropi, M.S. Beta-caryophyllene: A sesquiterpene with countless biological properties. Appl. Sci. 2019, 9, 9-19. [CrossRef]

3. Meza, A.; Lehmann, C. Betacaryophyllene-A phytocannabinoid as potential therapeutic modality for human sepsis? Med. Hypotheses 2018, 110, 68-70. [CrossRef] [PubMed]

4. Sharma, C.; Al Kaabi, J.M.; Nurulain, S.M.; Goyal, S.N.; Kamal, M.A.; Ojha, S. Polypharmacological properties and therapeutic potential of beta-caryophyllene: A dietary phytocannabinoid of pharmaceutical promise. Curr. Pharm. Des. 2016, 22, 3237-3264. [CrossRef]

5. Schmitt, D.; Levy, R.; Carroll, B. Toxicological evaluation of -caryophyllene oil: Subchronic toxicity in rats. Int. J. Toxicol. 2016, 35, 558-567. [CrossRef] 
6. Oliveira, G.L.D.; Machado, K.C.; Machado, K.C.; da Silva, A.; Feitosa, C.M.; Almeida, F.R.D. Non-clinical toxicity of beta-caryophyllene, a dietary cannabinoid: Absence of adverse effects in female swiss mice. Regul. Toxicol. Pharmacol. 2018, 92, 338-346. [CrossRef] [PubMed]

7. Wu, C.; Jia, Y.; Lee, J.H.; Jun, H.J.; Lee, H.S.; Hwang, K.Y.; Lee, S.J. Trans-caryophyllene is a natural agonistic ligand for peroxisome proliferator-activated receptor-alpha. Bioorg. Med. Chem. Lett. 2014, 24, 3168-3174. [CrossRef] [PubMed]

8. Geddo, F.; Scandiffio, R.; Antoniotti, S.; Cottone, E.; Querio, G.; Maffei, M.E.; Bovolin, P.; Gallo, M.P. Pipenig (r)-fl, a fluid extract of black pepper (Piper nigrum L.) with a high standardized content of trans-beta-caryophyllene, reduces lipid accumulation in 3t3-11 preadipocytes and improves glucose uptake in c2c12 myotubes. Nutrients 2019, 11, 2788. [CrossRef] [PubMed]

9. Dhopeshwarkar, A.; Mackie, K. Cb2 cannabinoid receptors as a therapeutic target-what does the future hold? Mol. Pharmacol. 2014, 86, 430-437. [CrossRef] [PubMed]

10. Katsuyama, S.; Mizoguchi, H.; Kuwahata, H.; Komatsu, T.; Nagaoka, K.; Nakamura, H.; Bagetta, G.; Sakurada, T.; Sakurada, S. Involvement of peripheral cannabinoid and opioid receptors in -caryophyllene-induced antinociception. Eur. J. Pain 2013, 17, 664-675. [CrossRef]

11. Commission, E.; Decree Regulating the Use of Vegetable Substances and Preparations in Food Supplements, Replacing the Decree of the Minister for Health of 9 July 2012. Communication from the Commission-TRIS/(2017) 01619 2017. Notification Number: 2017/276/I. Available online: https://ec. europa.eu/growth/tools-databases/tris/en/search/?trisaction=search.detail\&year=2017\&num=276 (accessed on 6 September 2020).

12. Zhaleh, M.; Sohrabi, N.; Zangeneh, M.M.; Zangeneh, A.; Moradi, R.; Zhaleh, H. Chemical composition and antibacterial effects of essential oil of Rhus Coriaria fruits in the west of Iran (Kermanshah). J. Essent. Oil Bear. Plants 2018, 21, 493-501. [CrossRef]

13. Sameh, S.; Al-Sayed, E.; Labib, R.M.; Singab, A.N.B. Comparative metabolic profiling of essential oils from Spondias Pinnata (linn. F.) kurz and characterization of their antibacterial activities. Ind. Crop Prod. 2019, 137, 468-474. [CrossRef]

14. Kossouoh, C.; Moudachirou, M.; Adjakidje, V.; Chalchat, J.C.; Figueredo, G. Essential oil chemical composition of Annona Muricata L. Leaves from Benin. J. Essent. Oil Res. 2007, 19, 307-309. [CrossRef]

15. Andrade, E.H.A.; Oliveira, J.; Zoghbi, M.D.B. Volatiles of Anaxagorea Dolichocarpa Spreng. \& sandw. and Annona Densicoma mart. growing wild in the state of para, Brazil. Flavour Frag. J. 2007, 22, 158-160.

16. Nebie, R.H.C.; Yameogo, R.T.; Belanger, A.; Sib, F.S. Chemical composition of leaf essential oil of Annona Senegalensis pers. from Burkina Faso. J. Essent. Oil Res. 2005, 17, 331-332. [CrossRef]

17. Garg, S.N.; Gupta, D. Composition of the leaf oil of Annona squamosa L. from the north Indian plains. J. Essent. Oil Res. 2005, 17, 257-258. [CrossRef]

18. Phan, G.M.; Phan, S.T.; Konig, W.A. Chemical composition of the flower essential oil of Artabotrys Hexapetalus (L. F.) bhandare of Vietnam. J. Essent. Oil Res. 2007, 19, 523-524. [CrossRef]

19. Brophy, J.; Goldsack, R.; Forster, P. Essential oils from the leaves of some queensland Annonaceae. J. Essent. Oil Res. 2004, 16, 95-100. [CrossRef]

20. Ouattara, Z.A.; Boti, J.B.; Ahibo, C.A.; Tomi, F.; Casanova, J.; Bighelli, A. Chemical composition of the leaf oil of Cleistopholis Glauca Pierre ex engler E diels from Cote d'Ivoire. J. Essent. Oil Res. 2012, 24, 471-474.

21. Hoferl, M.; Dai, D.N.; Thang, T.D.; Jirovetz, L.; Schmidt, E. Leaf essential oils of six vietnamese species of Fissistigma (Annonaceae). Nat. Prod. Commun. 2013, 8, 663-665. [CrossRef]

22. Thang, T.D.; Dai, D.N.; Ogunwande, I.A. Identification of the volatile compounds in the leaf and stem bark of three Goniothalamus species from Vietnam. J. Essent. Oil Bear. Plants 2016, 19, 743-749. [CrossRef]

23. Brophy, J.J.; Goldsack, R.J.; Forster, P.I. The leaf oils of the queensland species of Melodorum (Annonaceae). J. Essent. Oil Res. 2004, 16, 483-486. [CrossRef]

24. Brophy, J.J.; Goldsack, R.J.; Forster, P.I. The leaf oils of the australian species of Miliusa (Annonaceae). J. Essent. Oil Res. 2004, 16, 253-255. [CrossRef]

25. Ouattara, Z.A.; Boti, J.B.; Ahibo, C.A.; Bekro, Y.A.; Casanova, J.; Tomi, F.; Bighelli, A. Composition and chemical variability of Ivoirian Polyalthia Oliveri leaf oil. Chem. Biodivers. 2016, 13, 293-298. [CrossRef] [PubMed]

26. Brophy, J.J.; Goldsack, R.J.; Hook, J.M.; Fookes, C.J.R.; Forster, P.I. The leaf essential oils of the australian species of Pseuduvaria (Annonaceae). J. Essent. Oil Res. 2004, 16, 362-366. [CrossRef] 
27. Boyorn, F.F.; Zollo, P.H.A.; Agnaniet, H.; Menut, C.; Bessiere, J.M. Aromatic plants of tropical Central Africa. Xl. Essential oils from Uvariodendron Calophylium re fries growing in cameroon. J. Essent. Oil Res. 2005, 17, 128-129.

28. Lazarevic, J.; Radulovic, N.; Palic, R.; Zlatkovic, B. Chemical analysis of volatile constituents of Berula Erecta (Hudson) Coville Subsp Erecta (Apiaceae) from Serbia. J. Essent. Oil Res. 2010, 22, 153-156. [CrossRef]

29. Kurkcuoglu, M. Essential oil composition from fruits and aerial parts of Bilacunaria anatolica a. Duran (Apiaceae) endemic in Turkey. J. Essent. Oil Bear. Plants 2016, 19, 379-383. [CrossRef]

30. Oyedeji, O.A.; Afolayan, A.J. Chemical composition and antibacterial activity of the essential oil of Centella Asiatica growing in South Africa. Pharm. Biol. 2005, 43, 249-252. [CrossRef]

31. Masoudi, S.; Esmaeili, A.; Khalilzadeh, M.A.; Rustaiyan, A.; Moazami, N.; Akhgar, M.R.; Varavipoor, M. Volatile constituents of Dorema Aucheri boiss., Seseli Libanotis (L.) w. D. Koch var. Armeniacum Bordz. and conium Maculatum L. Three umbelliferae herbs growing wild in Iran. Flavour Frag. J. 2006, 21, 801-804. [CrossRef]

32. Akbarian, A.; Rahimmalek, M.; Sabzalian, M.R. Variation in essential oil yield and composition of Dorema Aucheri Boiss., an endemic medicinal plant collected from wild populations in natural habitats. Chem. Biodivers. 2016, 13, 1756-1766. [CrossRef]

33. Pala-Paul, J.; Brophy, J.J.; Goldsack, R.J.; Copeland, L.M.; Perez-Alonso, M.J.; Velasco-Negueruela, A. Essential oil composition of the seasonal Heterophyllous leaves of Eryngium Vesiculosum from Australia. Aust. J. Bot. 2003, 51, 497-501. [CrossRef]

34. Sahebkar, A.; Iranshahi, M. Volatile constituents of the genus ferula (Apiaceae): A review. J. Essent. Oil Bear. Plants 2011, 14, 504-531. [CrossRef]

35. Kucukboyaci, N.; Demirci, B.; Adiguzel, N.; Bani, B.; Baser, K.H.C. Volatile compounds from the aerial part and fruits of Grammosciadium Pterocarpum boiss. growing in Turkey. J. Essent. Oil Res. 2015, 27, 177-181. [CrossRef]

36. Khalilzadeh, M.A.; Tajbakhsh, M.; Gholami, F.A.; Hosseinzadeh, M.; Dastoorani, P.; Norouzi, M.; Dabiri, H.A. Composition of the essential oils of Hippomarathrum Microcarpum (m. Bieb.) b. Fedtsch. And Physospermum Cornubiense (L.) dc. from Iran. J. Essent. Oil Res. 2007, 19, 567-568. [CrossRef]

37. Baser, K.H.C.; Ozek, T.; Aytac, Z. Essential oil of Hippomarathrum Boissieri Reuter et Hausskn. J. Essent. Oil Res. 2000, 12, 231-232. [CrossRef]

38. Masoudi, S.; Ameri, N.; Rustaiyan, A.; Moradalizadeh, M.; Azar, P.A. Volatile constituents of three umbelliferae herbs: Azilia Eryngioedes (pau) hedge et lamond, Laser Trilobum (L.) borkh. and Falcaria Falcarioides (bornm. Et wolff) growing wild in Iran. J. Essent. Oil Res. 2005, 17, 98-100. [CrossRef]

39. Pino, J.A.; Fernandes, P.; Marbot, R.; Rosado, A.; Fontinha, S.S. Leaf oils of Helichrysum Melaleucum Rchb. Ex Holl, Oenanthe Divaricata (r. Br.) mabb. and Persea Indica (L.) spreng. from Madeira. J. Essent. Oil Res. 2004, 16, 487-489. [CrossRef]

40. Zhang, H.M.; Guo, S.S.; Fan, B.; Du, S.S.; Wang, Y.Y.; Deng, Z.W. Evaluation of efficacy of the essential oil from Ostericum Viridiflorum (turcz.) kitagawa in control of stored product insects. Environ. Sci. Pollut. Res. 2019, 26, 1406-1413. [CrossRef]

41. Askari, F.; Teimouri, M.; Sefidkon, F. Chemical composition and antimicrobial activity of Pimpinella Kotschyana boiss. Oil in Iran. J. Essent. Oil Bear. Plants 2011, 14, 124-130. [CrossRef]

42. Mazloomifar, H.; Bigdeli, M.; Saber-Tehrani, M.; Rustaiyan, A.; Masoudi, S.; Ameri, N. Essential oil of Prangos Uloptera dc. From Iran. J. Essent. Oil Res. 2004, 16, 415-416. [CrossRef]

43. Shafaghat, A. Comparison of chemical composition of essential oil and n-hexane extracts of Zosimia absinthifolia (vent.) link. J. Essent. Oil Bear. Plants 2011, 14, 490-493. [CrossRef]

44. Maia, J.G.S.; Zoghbi, M.B.; Andrade, E.H.A.; Carreira, L.M.M. Volatiles from flowers of Thevetia Peruviana (pers.) k. Schum. and Allamanda cathartics linn. (Apocynaceae). J. Essent. Oil Res. 2000, 12, 322-324. [CrossRef]

45. Cornelio, M.L.; Lago, J.H.G.; Moreno, P.R.H. Volatile oil composition of Aspidosperma Cylindrocarpon muelL. Arg. Leaves. J. Essent. Oil Res. 2005, 17, 310-311. [CrossRef]

46. Boligon, A.A.; Schwanz, T.G.; Piana, M.; Bandeira, R.V.; Frohlich, J.K.; de Brum, T.F.; Zadra, M.; Athayde, M.L. Chemical composition and antioxidant activity of the essential oil of Tabernaemontana Catharinensis a. Dc. Leaves. Nat. Prod. Res. 2013, 27, 68-71. [CrossRef] 
47. Sabulal, B.; George, V.; Pradeep, N.S.; Dan, M. Volatile oils from the root, stem and leaves of Schefflera Stellata (gaertn.) harms (araliaceae): Chemical characterization and antimicrobial activity. J. Essent. Oil Res. 2008, 20, 79-82. [CrossRef]

48. Vila, R.; Mundina, M.; Muschietti, L.; Priestap, H.A.; Bandoni, A.L.; Adzet, T.; Canigueral, S. Volatile constituents of leaves, roots and stems from aristolochia elegans. Phytochemistry 1997, 46, 1127-1129. [CrossRef]

49. Su, X.D.; Gao, Y.; Xiang, Y.X.; Lai, P.X.; Xing, X. Chemical composition and biological activities of the essential oil from Aristolochia Fordiana hemsl. Rec. Nat. Prod. 2019, 13, 346-354.

50. Simic, N.; Palic, R.; Vajs, V.; Milosavljevic, S.; Djokovic, D. Composition and antibacterial activity of Achillea Asplenifolia essential oil. J. Essent. Oil Res. 2002, 14, 76-78. [CrossRef]

51. Rodrigues, R.A.F.; Queiroga, C.L.; Rodrigues, M.V.N.; Foglio, M.A.; Sartoratto, A.; Montanari, I. Study of the variation of the composition of the essential oil of leaves and flowers of Achyrocline Alata (dc) along a period of the day. J. Essent. Oil Res. 2002, 14, 280-281. [CrossRef]

52. Norouzi-Arasi, H.; Yavari, I.; Chalabian, F.; Kiarostami, V.; Ghaffarzadeh, F.; Nasirian, A. Chemical constituents and antimicrobial activities of the essential oil of Acroptilon Repens (L.) dc. Flavour Frag. J. 2006, 21, 247-249. [CrossRef]

53. Del-Vechio-Vieira, G.; Sousa, O.V.; Yamamoto, C.H.; Kaplan, M.A.C. Chemical composition and antimicrobial activity of the essential oils of Ageratum Fastigiatum (asteraceae). Rec. Nat. Prod. 2009, 3, 52-57.

54. Martins, A.P.; Salgueiro, U.R.; Goncalves, M.J.; Vila, R.; Canigueral, S.; Tomi, F.; Casanova, J. Essential oil composition and antimicrobial activity of ageratum conyzoides from s. Tome and principe. J. Essent. Oil Res. 2005, 17, 239-242. [CrossRef]

55. Javidnia, K.; Miri, R.; Kamalinejad, M.; Sarkarzadeh, H.; Jamalian, A. Chemical composition of the essential oils of anthemis altissima L. Grown in Iran. Flavour Frag. J. 2004, 19, 213-216. [CrossRef]

56. Juteau, F.; Masotti, V.; Viano, J.; Bessiere, J.M. Chemical variation in the oil of Artemisia Verlotiorum lamotte of french origin harvested at a vegetative stage and during flowering. J. Essent. Oil Res. 2005, 17, 254-256. [CrossRef]

57. Rana, V.S.; Juyal, A.P.; Blazquez, M.A.; Bodakhe, S.H. Essential oil composition of Artemisia Parviflora aerial parts. Flavour Frag. J. 2003, 18, 342-344. [CrossRef]

58. Haider, F.; Kumar, N.; Banerjee, S.; Naqvi, A.A.; Bagchi, G.D. Effect of altitude on the essential oil constituents of Artemisia Roxburghiana besser var. Purpurascens (jacq.) hook. J. Essent. Oil Res. 2009, 21, 303-304. [CrossRef]

59. Cha, J.D.; Jeong, M.R.; Jeong, S.I.; Moon, S.E.; Kim, J.Y.; Kil, B.S.; Song, Y.H. Chemical composition and antimicrobial activity of the essential oils of Artemisia Scoparia and a-capillaris. Planta Med. 2005, 71, 186-190. [CrossRef]

60. Manika, N.; Chanotiya, C.S.; Darokar, M.; Singh, S.; Das Bagchi, G. Compositional characters and antimicrobial potential of Artemisia Stricta edgew. F. Stricta pamp. Essential oil. Rec. Nat. Prod. 2016, 10, 40-46.

61. Cha, J.D.; Jeong, M.R.; Choi, H.J.; Jeong, S.; Moon, S.E.; Yun, S.; Kim, Y.H.; Kil, B.S.; Song, Y.H. Chemical composition and antimicrobial activity of the essential oil of Artemisia Lavandulaefolia. Planta Med. 2005, 71, 575-577. [CrossRef]

62. Gbolade, A.A.; Dzamic, A.; Marin, P.D.; Ristic, M. Essential oil constituents of Aspilia Africana (pers.) c. D. Adams leaf from Nigeria. J. Essent. Oil Res. 2009, 21, 348-350. [CrossRef]

63. Zunino, M.P.; Newton, M.N.; Maestri, D.M.; Zygadlo, J.A. Essential oils of three baccharis species. Planta Med. 1998, 64, 86-87. [CrossRef] [PubMed]

64. Zollo, P.H.A.; Kuiate, J.R.; Menut, C.; Lamaty, G.; Bessiere, J.M.; Chalchat, J.C.; Garry, R.P. Aromatic plants of tropical central Africa. Part xx. The occurrence of 1-phenylhepta-1,3,5-triyne in the essential oil of bidens pilosa L. From Cameroon. Flavour Frag. J. 1995, 10, 97-100. [CrossRef]

65. Novakovic, J.; Rajcevic, N.; Garcia-Jacas, N.; Susanna, A.; Marin, P.D.; Janackovic, P. Capitula essential oil composition of seven centaurea species (sect. Acrocentron, asteraceae)-Taxonomic implication and ecological significance. Biochem. Syst. Ecol. 2019, 83, 83-90. [CrossRef]

66. Yayli, N.; Yasar, A.; Albay, C.; Asamaz, Y.; Coskuncelebi, K.; Karaoglu, S. Chemical composition and antimicrobial activity of essential oils from Centaurea Appendicigera and Centaurea Helenioides. Pharm. Biol. 2009, 47, 7-12. [CrossRef] 
67. Ogunwande, I.A.; Olawore, N.O.; Usman, L. Composition of the leaf oil of Centratherum Punctatum cass. Growing in Nigeria. J. Essent. Oil Res. 2005, 17, 496-498. [CrossRef]

68. Koba, K.; Nenonene, A.Y.; Catherine, G.; Raynaud, C.; Chaumont, J.P.; Sanda, K.; Laurence, N. Chemical composition and cytotoxic activity of essential oil of Chromolaena Odorata L. Growing in Togo. J. Essent. Oil Bear. Plants 2011, 14, 423-429. [CrossRef]

69. Maia, J.G.S.; da Silva, M.H.L.; Zoghbi, M.D.B.; Andrade, E.H.A. Composition of the essential oils of Conyza Bonariensis (L.) cronquist. J. Essent. Oil Res. 2002, 14, 325-326. [CrossRef]

70. Boue, G.B.; Boti, J.B.; Tonzibo, Z.F.; Paoli, M.; Bighelli, A. New trans-beta-bergamotene derivatives in the root and the flower essential oils of Cyanthillium Cinereum (L.) h. Rob. From cote d'Ivoire. Nat. Prod. Res. 2019, 33, 2795-2800. [CrossRef]

71. Zhang, W.J.; You, C.X.; Yang, K.; Wang, Y.; Su, Y.; Geng, Z.F.; Du, S.S.; Wang, C.F.; Deng, Z.W.; Wang, Y.Y. Bioactivity and chemical constituents of the essential oil from Dendranthema Indicum (L.) des moul. Against two stored insects. J. Oleo Sci. 2015, 64, 553-560. [CrossRef]

72. Joshi, R.K. Volatile constituents of Emilia Sonchifolia from India. Nat. Prod. Commun. 2018, 13, 1355-1356. [CrossRef]

73. Idrissa, M.; Djibo, A.K.; Khalid, I.; Marie, B.J. The essential oil of Epaltes Alata (compositae). Flavour Frag. J. 2005, 20, 203-204. [CrossRef]

74. Pinto, A.P.R.; Seibert, J.B.; dos Santos, O.D.H.; Vieira, S.A.; do Nascimento, A.M. Chemical constituents and allelopathic activity of the essential oil from leaves of Eremanthus Erythropappus. Aust. J. Bot. 2018, 66, 601-608. [CrossRef]

75. Rahman, A.; Hossain, M.A.; Kang, S.C. Control of phytopathogenic fungi by the essential oil and methanolic extracts of Erigeron Ramosus (walt.) bsp. Eur. J. Plant Pathol. 2010, 128, 211-219. [CrossRef]

76. Viljoen, A.M.; Njenga, E.W.; van Vuuren, S.F.; Bicchi, C.; Rubiolo, P.; Sgorbini, B. Essential oil composition and in vitro biological activities of seven namibian species of eriocephalus L. (asteraceae). J. Essent. Oil Res. 2006, 18, 124-128. [CrossRef]

77. Gupta, D.; Charles, R.; Garg, S.N. Chemical composition of the essential oil from the leaves of Eupatorium Triplinerve vahl. J. Essent. Oil Res. 2004, 16, 473-475. [CrossRef]

78. Silva, M.P.; Piazza, L.A.; Lopez, D.; Rivilli, M.J.L.; Turco, M.D.; Cantero, J.J.; Tourn, M.G.; Scopel, A.L. Phytotoxic activity in Flourensia Campestris and isolation of (-)-hamanasic acid a as its active principle compound. Phytochemistry 2012, 77, 140-148. [CrossRef]

79. Rabehaja, D.J.R.; Bezert, G.; Rakotonandrasana, S.R.; Ramanoelina, P.A.R.; Andrianjara, C.; Bighelli, A.; Tomi, F.; Paoli, M. Chemical composition of aerial parts essential oils from six endemic Malagasy Helichrysum species. Plants 2020, 9, 14. [CrossRef]

80. Bougatsos, C.; Meyer, J.J.M.; Magiatis, P.; Vagias, C.; Chinou, I.B. Composition and antimicrobial activity of the essential oils of Helichrysum Kraussii sch. Bip. And h-rugulosum less. From South Africa. Flavour Frag. J. 2003, 18, 48-51. [CrossRef]

81. Pino, J.A.; Marbot, R.; Payo, A.; Chao, D.; Herrera, P.; Marti, M.P. Leaf oil of Koanophyllon Villosum (sw.) king et robins. J. Essent. Oil Res. 2005, 17, 427-428. [CrossRef]

82. Kuiate, J.R.; Bessiere, J.M.; Zollo, P.H.A. Composition of the essential oils from three laggera spp. From Cameroon. Flavour Frag. J. 2002, 17, 105-108. [CrossRef]

83. Mwangi, J.W.; Thoithi, G.N.; Juliani, H.R.; Zygadlo, J.A. Composition of the essential oil of Microglossa Pyrrhopappa (a. Rich) agnew var. Pyrrhopappa from Kenya. J. Essent. Oil Res. 2001, 13, 229-230. [CrossRef]

84. Pelissier, Y.; Marion, C.; Kone, D.; Brunel, J.F.; Fofana, H.; Bessiere, J.M. Volatile constituents of the leaves of Mikania Cordata (burm.F.) b.L. Robinson var. Cordata (asteraceae). J. Essent. Oil Res. 2001, 13, 31-32. [CrossRef]

85. Villarreal, S.; Solorzano, M.; Velasco, J.; Diaz, T.; Rojas, L.B.; Usubillaga, A.; Ramirez-Gonzalez, I. Composition and in vitro antibacterial activity of essential oil of Oyedaea Verbesinoides dc from Venezuela. J. Essent. Oil Bear. Plants 2008, 11, 643-648. [CrossRef]

86. Ciccio, J.F.; Chaverri, C. Chemical composition of the leaf and branch oils of Perymenium Grande hemsl. Var. Nelsonii (robins. \& greenm.) fay (asteraceae-heliantheae) from Costa Rica. Rec. Nat. Prod. 2012, 6, 371-375.

87. Miyazawa, M.; Teranishi, A.; Ishikawa, Y. Components of the essential oil from Petasites Japonicus. Flavour Frag. J. 2003, 18, 231-233. [CrossRef] 
88. Kerdudo, A.; Gonnot, V.; Ellong, E.N.; Boyer, L.; Chandre, F.; Adenet, S.; Rochefort, K.; Michel, T.; Fernandez, X. Composition and bioactivity of Pluchea Carolinensis (jack.) g. Essential oil from Martinique. Ind. Crop Prod. 2016, 89, 295-302. [CrossRef]

89. Labuckas, D.O.; Zygadlo, J.A.; Espinar, L.A. Constituents of the volatile oil of Porophyllum Obscurum (spreng.) dc. Flavour Frag. J. 1999, 14, 107-108. [CrossRef]

90. Zhu, X.W.; Zhang, X.H.; Chen, J.H.; Zhu, X.W.; Tan, J.C.; Chen, H.X.; Wan, F.H. Chemical composition of leaf essential oil from Solidago Decurrens lour. J. Essent. Oil Res. 2009, 21, 354-356. [CrossRef]

91. Szarka, S.; Hethelyi, E.; Lemberkovics, E.; Kuzovkina, I.N.; Banyai, P.; Szoke, E. Gc and gc-ms studies on the essential oil and thiophenes from Tagetes Patula L. Chromatographia 2006, 63, S67-S73. [CrossRef]

92. Sefidkon, F.; Salehyar, S.; Mirza, M.; Dabiri, M. The essential oil of Tagetes Erecta L. Occurring in Iran. Flavour Frag. J. 2004, 19, 579-581. [CrossRef]

93. Shafaghat, A. Antibacterial activity and sesquiterpenoid contents of the essential oil of Tanacetum Punctatum (desr.) grierson. J. Essent. Oil Bear. Plants 2012, 15, 270-275. [CrossRef]

94. Nanyonga, S.K.; Opoku, A.R.; Lewu, F.B.; Oyedeji, A.O. The chemical composition, larvicidal and antibacterial activities of the essential oil of Tarchonanthus Trilobus var galpinii. J. Essent. Oil Bear. Plants 2013, 16, 524-530. [CrossRef]

95. Sobrinho, A.C.N.; dos Santos, H.S.; de Morais, S.M.; Cavalcante, C.S.D.; de Souza, E.B.; de Sousa, H.A.; Albuquerque, M.; Fontenelle, R.O.D. Antifungal and antioxidant activities of Vernonia Chalybaea mart. Ex dc. Essential oil and their major constituent beta-caryophyllene. Braz. Arch. Biol. Technol. 2020, 63, 11.

96. Albuquerque, M.; Lemos, T.L.G.; Pessoa, O.D.L.; Nunes, E.P.; Nascimento, R.F.; Silveira, E.R. Chemical composition of the essential oil from Vernonia Scorpioides (asteraceae). Flavour Frag. J. 2007, 22, 249-250. [CrossRef]

97. Parveen, Z.; Mazhar, S.; Siddique, S.; Manzoor, A.; Ali, Z. Chemical composition and antifungal activity of essential oil from Xanthium Strumarium L. Leaves. Indian J. Pharm. Sci. 2017, 79, 316. [CrossRef]

98. Uquiche, E.L.; Toro, M.T.; Quevedo, R.A. Supercritical extraction with carbon dioxide and co-solvent from Leptocarpha Rivularis. J. Appl. Res. Med. Aromat. Plants 2019, 14, 8. [CrossRef]

99. Brophy, J.J.; Forster, P.I.; Goldsack, R.J. Characterization of essential oils from the leaves of the genus daphnandra (atherospermataceae). J. Essent. Oil Res. 2016, 28, 339-347. [CrossRef]

100. Diniz, J.C.; Viana, F.A.; de Oliveira, O.F.; Silveira, E.R.; Pessoa, O.D.L. Chemical composition of the leaf essential oil of Cordia Leucocephala moric from north-east of Brazil. J. Essent. Oil Res. 2008, 20, 495-496. [CrossRef]

101. Das Gracas, M.; Zoghbi, B.; Andrade, E.H.A.; Pereira, R.A.; Oliveira, J. Volatiles of the Cordia Multispicata cham.: A weed medicinal Brazilian plant. J. Essent. Oil Res. 2010, 22, 543-545. [CrossRef]

102. Junor, G.A.O.; Porter, R.B.R.; Yee, T.H.; Waugh, T. The volatile constituents from the leaves, bark and fruits of Bursera Aromatica (proctor) found in Jamaica. J. Essent. Oil Res. 2010, 22, 19-22. [CrossRef]

103. Tucker, A.O.; Maciarello, M.J.; Brown, R.C.; Landrum, L.R.; Lafferty, D. Essential oils from the oleo-gum-resins of elephant tree or torote (Bursera Microphylla a. Gray, burseraceae) from Arizona. J. Essent. Oil Res. 2009, 21, 57-58. [CrossRef]

104. Thang, T.D.; Dai, D.N.; Luong, N.X.; Ogunwande, I.A. Constituents of essential oils from the leaves, stem barks and resins of Canarium Parvum leen., and Canarium Tramdenanum dai et yakovl. (burseracea) grown in vietnam. Nat. Prod. Res. 2014, 28, 461-466. [CrossRef]

105. Onocha, P.A.; Ekundayo, O.; Oyelola, O.; Laakso, I. Essential oils of Dacryodes Edulis (g.Don) h. J. Lam (african pear). Flavour Frag. J. 1999, 14, 135-139. [CrossRef]

106. Bandeira, P.N.; Machado, M.I.L.; Cavalcanti, F.S.; Lemos, T.L.G. Essential oil composition of leaves, fruits and resin of Protium Heptaphyllum (aubl.) march. J. Essent. Oil Res. 2001, 13, 33-34. [CrossRef]

107. Novak, J.; Franz, C. Composition of the essential oils and extracts of two populations of Cannabis Sativa L. Ssp spontanea from Austria. J. Essent. Oil Res. 2003, 15, 158-160. [CrossRef]

108. Benelli, G.; Pavela, R.; Petrelli, R.; Cappellacci, L.; Santini, G.; Fiorini, D.; Sut, S.; Dall'Acqua, S.; Canale, A.; Maggi, F. The essential oil from industrial hemp (Cannabis Sativa L.) by-products as an effective tool for insect pest management in organic crops. Ind. Crop Prod. 2018, 122, 308-315. [CrossRef]

109. Goncalves, J.; Figueira, J.; Rodrigues, F.; Camara, J.S. Headspace solid-phase microextraction combined with mass spectrometry as a powerful analytical tool for profiling the terpenoid metabolomic pattern of hop-essential oil derived from saaz variety. J. Sep. Sci. 2012, 35, 2282-2296. [CrossRef] 
110. Poralijan, V.; Rad, A.S. Extraction of eugenol from carnation: A quantitative and qualitative analysis by aqueous and ethanolic solvents. J. Essent. Oil Bear. Plants 2016, 19, 1495-1502. [CrossRef]

111. Mendiratta, A.; Dayal, R.; Bartley, J.R. Gc/ms analysis of essential oils of needles and twigs of Cephalotaxus Harringtonia (knight ex forbes) koch var. Harringtonia. J. Essent. Oil Res. 2005, 17, 308-309. [CrossRef]

112. De Oliveira, J.C.S.; Neves, I.A.; da Camara, C.A.G.; Schwartz, M.O.E. Volatile constituents of the fruits of Clusia Nemorasa G. Mey. From different region of Atlantic coast restingas of pernambuco (northeast of Brazil). J. Essent. Oil Res. 2008, 20, 219-222. [CrossRef]

113. Tan, W.N.; Wong, K.C.; Khairuddean, M.; Eldeen, I.M.; Asmawi, M.Z.; Sulaiman, B. Volatile constituents of the fruit of Garcinia Atroviridis and their antibacterial and anti-inflammatory activities. Flavour Frag. J. 2013, 28, 2-9. [CrossRef]

114. Andrade, M.S.; Sampaio, T.S.; Nogueira, P.C.L.; Ribeiro, A.S.; Bittrich, V.; Amaral, M.D.E. Volatile compounds of the leaves, flowers and fruits of Kielmeyera Rugosa choisy (clusiaceae). Flavour Frag. J. 2007, 22, 49-52. [CrossRef]

115. Alitonou, G.; Avlessi, F.; Sohounhloue, D.C.K.; Bessiere, J.M.; Menut, C. Chemical and biological investigation on volatile constituents of Pentadesma Butyracea sabine (clusiaceae) from Benin. J. Essent. Oil Res. 2010, 22, 138-140. [CrossRef]

116. Zubair, M.F.; Oladosu, I.A.; Olawore, N.O. Chemical composition of the leaf oil of Psorospermum Corymbiferum hochr. Growing in Africa. J. Essent. Oil Res. 2010, 22, 529-530. [CrossRef]

117. Dehghan, H.; Sarrafi, Y.; Salehi, P. Chemical composition of the essential oil of Convolvulus Persicus L. J. Essent. Oil Bear. Plants 2015, 18, 592-595. [CrossRef]

118. Boudarene, L.; Rahim, L.; Baaliouamer, A.; Meklati, B.Y. Analysis of algerian essential oils from twigs, needles and wood of Cedrus Atlantica g. Manetti by gc/ms. J. Essent. Oil Res. 2004, 16, 531-534. [CrossRef]

119. Tort, N.S.; Demiray, H.; Guvensen, A.; Dereboylu, A.E. Chemical composition of essential oils of berries of Juniper Us Macrocarpa sibth. E sm. From Turkey. Bangladesh J. Bot. 2019, 48, 339-343.

120. Elsharkawy, E.R.; Aljohar, H.; Donia, A. Comparative study of antioxidant and anticancer activity of Thuja Orientalis growing in Egypt and Saudi Arabia. Br. J. Pharm. Res. 2017, 15, 9. [CrossRef]

121. Lazarevic, J.; Radulovic, N.; Palic, R.; Zlatkovic, B. Chemical composition of the essential oil of Cyperus Glomeratus L. (cyperaceae) from Serbia. J. Essent. Oil Res. 2010, 22, 578-581. [CrossRef]

122. Queiroz, T.B.; da Fonseca, F.S.A.; Mendes, A.D.R.; Azevedo, A.M.; Martins, E.R. Chemical diversity of accessions of the in vivo germplasm bank of Varronia Curassavica (jacq.). Acta Sci. Agron. 2020, 42, 11. [CrossRef]

123. Scotto, C.I.; Burger, P.; el Khil, M.K.; Ginouves, M.; Prevot, G.; Blanchet, D.; Delprete, P.G.; Fernandez, X. Chemical composition and antifungal activity of the essential oil of Varronia Schomburgkii (dc.) borhidi (cordiaceae) from plants cultivated in French Guiana. J. Essent. Oil Res. 2017, 29, 304-312. [CrossRef]

124. Deepaa, C.V.; Chalchat, J.C.; John, J.A. Chemical composition of the essential oil from the leaves of Acalypha Fruticosa. J. Essent. Oil Bear. Plants 2012, 15, 609-613. [CrossRef]

125. Nguyen, A.D.; Tran, D.T.; Hong, V.; Nguyen, X.D. Volatile constituents of the leaf oil of Alchornea Tiliifolia (benth.) muell. (family euphorbiaceae) from Vietnam. J. Essent. Oil Res. 2009, 21, 1-2.

126. Da Camara, C.A.G.; de Moraes, M.M.; de Melo, J.P.R.; da Silva, M.M.C. Chemical composition and acaricidal activity of essential oils from Croton Rhamnifolioides pax and hoffm. In different regions of a caatinga biome in northeastern Brazil. J. Essent. Oil Bear. Plants 2017, 20, 1434-1449. [CrossRef]

127. De Oliveira, L.F.; Damasceno, C.S.; Campos, R.; de Souza, A.M.; Mendes, G.; Dias, J.D.G.; Miguel, O.G.; Miguel, M.D. Chemical composition of the volatile oil of Croton Glandulosus linnaeus and its allelopathic activity. Nat. Prod. Res. 2020, 4, 1-4. [CrossRef]

128. Doria, G.A.A.; Silva, W.J.; Carvalho, G.A.; Alves, P.B.; Cavalcanti, S.C.H. A study of the larvicidal activity of two croton species from northeastern Brazil against Aedes Aegypti. Pharm. Biol. 2010, 48, 615-620. [CrossRef]

129. Eresanya, O.I.; Avoseh, O.N.; Ogunwande, I.A.; Lawal, O.A.; Giwa-Ajeniya, A.F. Chemical constituents of essential oil from the leaves of Phyllanthus Muellerianus (o. Kuntze) exell. J. Essent. Oil Bear. Plants 2019, 22, 865-870. [CrossRef]

130. Da Silva, K.L.C.; da Silva, M.M.C.; de Moraes, M.M.; da Camara, C.A.G.; Santos, M.L.; Fagg, C.W. Chemical composition and acaricidal activity of essential oils from two species of the genus bauhinia that occur in the cerrado biome in Brazil. J. Essent. Oil Res. 2020, 32, 93-101. [CrossRef] 
131. Rodrigues, M.O.; Alves, P.B.; Nogueira, P.C.L.; Machado, S.M.F.; Moraes, V.R.S.; Ribeiro, A.D.; Silva, E.S.; Feitosa, J.G.R. Volatile constituents and antibacterial activity from seeds of Bowdichia Virgilioides kunt. J. Essent. Oil Res. 2009, 21, 286-288. [CrossRef]

132. Miyazawa, M.; Nagata, T.; Nakahashi, H.; Takahashi, T. Characteristic odor components of essential oil from Caesalpinia Decapetala. J. Essent. Oil Res. 2012, 24, 441-446. [CrossRef]

133. De Oliveira, L.G.S.; Ribeiro, D.A.; Saraiva, M.E.; de Macedo, D.G.; Macedo, J.G.F.; Pinheiro, P.G.; da Costa, J.G.M.; Souza, M.M.D.; de Menezes, I.R.A. Chemical variability of essential oils of Copaifera Langsdorffii desf. In different phenological phases on a savannah in the northeast, Ceara, Brazil. Ind. Crop Prod. 2017, 97 , 455-464. [CrossRef]

134. Veiga, V.F.; Rosas, E.C.; Carvalho, M.V.; Henriques, M.; Pinto, A.C. Chemical composition and anti-inflammatory activity of copaiba oils from Copaifera Cearensis Huber Ex Ducke, Copaifera Reticulata ducke and Copaifera Multijuga hayne-A comparative study. J. Ethnopharmacol. 2007, 112, 248-254. [CrossRef] [PubMed]

135. Zoghbi, M.D.B.; Andrade, E.H.A.; Martins-da-Silva, R.C.V.; Trigo, J.R. Chemical variation in the volatiles of Copaifera Reticulata ducke (leguminosae) growing wild in the states of para and amapa, Brazil. J. Essent. Oil Res. 2009, 21, 501-503. [CrossRef]

136. Munoz-Acevedo, A.; Gonzalez, M.D.; Stashenko, E.E. Volatile fractions and essential oils of the leaves and branches of Dalea Carthagenensis (jacq.) jf macbr. From northern region of Colombia. J. Essent. Oil Bear. Plants 2019, 22, 774-788. [CrossRef]

137. Leandro, L.M.; Da Veiga, V.F.; Sales, A.P.B.; Pessoa, C.D. Chemical composition and cytotoxic activity of essential oils from the leaves and stems of Eperua Duckeana cowan. Boletin Latinoamericano Y Del Caribe de Plantas 2015, 14, 42-47.

138. Shakeri, A.; Akhtari, J.; Soheili, V.; Taghizadeh, S.F.; Sahebkar, A.; Shaddel, R.; Asili, J. Identification and biological activity of the volatile compounds of Glycyrrhiza Triphylla fisch \& camey. Microb. Pathog. 2017, 109, $39-44$.

139. Bertoli, A.; Menichini, F.; Noccioli, C.; Morelli, L.; Pistelli, L. Volatile constituents of different organs of Psoralea bituminosa L. Flavour Frag. J. 2004, 19, 166-171. [CrossRef]

140. Mwangi, J.W.; Thoithi, G.N.; Kibwage, I.O.; Demo, M.S.; Oliva, M.M.; Zunino, M.R.; Zygadlo, J.A. Essential oil of Rynchosia Minima dc. From kenya: Composition and antibacterial properties. J. Essent. Oil Res. 2005, 17, 230-231. [CrossRef]

141. Stefanello, M.E.A.; Wisniewski, A.; Simionatto, E.L.; Cervi, A.C. Essential oil composition of Casearia Decandra jacq. J. Essent. Oil Res. 2010, 22, 157. [CrossRef]

142. Sousa, F.G.; Schneider, N.F.Z.; Mendes, C.E.; de Moura, N.F.; Denardin, R.B.N.; Matuo, R.; Mantovani, M.S. Clastogenic and anticlastogenic effect of the essential oil from Casearia Sylvestris swart. J. Essent. Oil Res. 2007, 19, 376-378. [CrossRef]

143. Tewari, K.; Pande, C.; Tewari, G.; Kharkwal, G.C.; Punetha, D. Volatile constituents of Geranium Wallichianum d. Don ex sweet. From north-western Himalayan region. J. Indian Chem. Soc. 2015, 92, 123-125.

144. Scramin, S.; Saito, M.L.; Pott, A.; Marques, M.O.M. Essential oil of Elyonurus Muticus (sprengel) o.Kuntze (gramineae). J. Essent. Oil Res. 2000, 12, 298-300. [CrossRef]

145. Kimani, S.M.; Chhabra, S.C.; Lwande, W.; Khan, Z.R.; Hassanali, A.; Pickett, J.A. Airborne volatiles from Melinis Minutiflora p. Beauv., a non-host plant of the spotted stem borer. J. Essent. Oil Res. 2000, 12, 221-224. [CrossRef]

146. Brophy, J.J.; Goldsack, R.J.; Forster, P.I. Leaf essential oils of the australian species of gyrocarpus and hernandia (hernandiaceae). J. Essent. Oil Res. 2000, 12, 717-722. [CrossRef]

147. Abreu, L.N.; Reis, M.G.; Marsaioli, A.J.; Mazzafera, P. Essential oil composition of Hypericum Brasiliense choise. Flavour Frag. J. 2004, 19, 80-82. [CrossRef]

148. Ghiasvand, A.; Shadabi, S.; Hajipour, S.; Nasirian, A.; Borzouei, M.; Hassani-Moghadam, E.; Hashemi, P. Comparison of ultrasound-assisted headspace solid-phase microextraction and hydrodistillation for the identification of major constituents in two species of hypericum. J. Chromatogr. Sci. 2016, 54, 264-270. [CrossRef]

149. Buitrago, A.; Rojas, L.B.; Rojas, J.; Buitrago, D.; Usubillaga, A.; Morales, A. Comparative study of the chemical composition of the essential oil of Vismia Baccifera var. Dealbata (guttiferae) collected in two different locations in Merida-Venezuala. J. Essent. Oil Bear. Plants 2009, 12, 651-655. [CrossRef] 
150. Rather, M.A.; Dar, B.A.; Dar, M.Y.; Wani, B.A.; Shah, W.A.; Bhat, B.A.; Ganai, B.A.; Bhat, K.A.; Anand, R.; Qurishi, M.A. Chemical composition, antioxidant and antibacterial activities of the leaf essential oil of Juglans regia L. And its constituents. Phytomedicine 2012, 19, 1185-1190. [CrossRef]

151. Luciano, J.H.S.; Barros, M.C.P.; Lima, M.A.S.; do Nascimento, R.F.; Silveira, E.R. Volatile composition of leaves from Aegiphila Lhotzkiana cham. Flavour Frag. J. 2005, 20, 537-538. [CrossRef]

152. Singh, P.; Prakash, O.; Pant, A.K. Essential oil composition of Ajuga parviflora benth. Growing in western Himalayan region of Uttarakhand (India). J. Essent. Oil Bear. Plants 2015, 18, 697-701. [CrossRef]

153. Karami, A. Essential oil composition of Ajuga comata stapf. From southern Zagros, Iran. Nat. Prod. Res. 2017, 31, 359-361. [CrossRef] [PubMed]

154. Sebaa, N.A.; Zatla, A.T.; Dib, M.E.A.; Tabti, B.; Costa, J.; Muselli, A. Antifungal activity of essential oil and hydrosol extract of Ballota nigra L. and their protective effects against the black rot of tomatoes. Curr. Nutr. Food Sci. 2019, 15, 662-671. [CrossRef]

155. Ogundajo, A.L.; Owoyele, O.A.; Ogunwande, I.A.; Owolabi, M.S. Chemical composition of essential oil from the leaves of Clerodendrum polycephalum baker growing in Nigeria. J. Essent. Oil Bear. Plants 2016, 19, 119-124. [CrossRef]

156. Bhaft, R.; Padalia, R.C.; Pande, C. Chemical composition of the essential oil of Colquhounia coccinea Wall. J. Essent. Oil Res. 2009, 21, 74-75.

157. Agostini, G.; Souza-Chies, T.T.; Agostini, F.; Atti-Serafini, L.; Echeverrigaray, S. Essential oil composition of Cunila incana benth. (lamiaceae). J. Essent. Oil Res. 2010, 22, 432-434. [CrossRef]

158. Nori-Shargh, D.; Baharvand, B. Volatile constituents analysis of Cyclotrichium strussii bornm. From Iran. J. Essent. Oil Res. 2006, 18, 261-262. [CrossRef]

159. Judzentiene, A.; Stoncius, A.; Budiene, J. Chemical composition of the essential oils from Glechoma hederacea plants grown under controlled environmental conditions in Lithuania. J. Essent. Oil Res. 2015, 27, 454-458. [CrossRef]

160. Venturi, C.R.; Danielli, L.J.; Klein, F.; Apel, M.A.; Montanha, J.A.; Bordignon, S.A.L.; Roehe, P.M.; Fuentefria, A.M.; Henriques, A.T. Chemical analysis and in vitro antiviral and antifungal activities of essential oils from Glechon spathulata and Glechon marifolia. Pharm. Biol. 2015, 53, 682-688. [CrossRef]

161. Tonzibo, Z.F.; Coffy, A.A.; Chalachat, J.C.; N'Guessan, Y.T. Chemical composition of essential oils of hoslundia opposita vahl. From Ivory Coast. Flavour Frag. J. 2006, 21, 789-791. [CrossRef]

162. Firouznia, A.; Rustaiyan, A.; Nadimi, M.; Masoudi, S.; Bigdeli, M. Composition of the essential oil of Hymenocrater calycinus (boiss.) benth. From Iran. J. Essent. Oil Res. 2005, 17, 527-529. [CrossRef]

163. Fiuza, T.S.; Saboia-Morais, S.M.T.; Paula, J.R.; Bara, M.T.F.; Tresvenzol, L.M.F.; Ferreira, H.D.; Ferri, P.H. Composition and chemical variability in the essential oils of Hyptidendron canum (pohl ex benth.) harley. J. Essent. Oil Res. 2010, 22, 159-163. [CrossRef]

164. Dambolena, J.S.; Zunino, M.P.; Lucini, E.I.; Zygadlo, J.A.; Rotman, A.; Ahumada, O.; Biurrun, F. Essential oils of plants used in home medicine in north of Argentina. J. Essent. Oil Res. 2009, 21, 405-409. [CrossRef]

165. Kossouoh, C.; Moudachirou, M.; Adjakidje, V.; Chalchat, J.C.; Figueredo, G. A comparative study of the chemical composition of the leaves and fruits deriving the essential oil of Hyptis suaveolens (L.) poit. From Benin. J. Essent. Oil Res. 2010, 22, 507-509. [CrossRef]

166. Yuce, E.; Bagci, E. Study of the essential oil composition of Lallenmantia iberica (m. Bieb.) fisch and ca mey. (lamiaceae) from Turkey. Asian J. Chem. 2012, 24, 4817-4818.

167. Oyedeji, O.A.; Afolayan, A. Comparative study of the essential oil composition and antimicrobial activity of leonotis leonurus and l-ocymifolia in the eastern Cape, South Africa. S. Afr. J. Bot. 2005, 71, 114-116. [CrossRef]

168. Joshi, R.K. Leucas aspera (willd.) link essential oil from India: Beta-caryophyllene and 1-octen-3-ol chemotypes. J. Chromatogr. Sci. 2016, 54, 295-298. [CrossRef]

169. Joshi, R.K. Gc/ms analysis of the essential oil of leucas indica from India. Nat. Prod. Commun. 2014, 9, 1607-1608. [CrossRef]

170. Demirci, B.; Baser, K.H.C.; Kirimer, N. Composition of the essential oil of Marrubium bourgaei ssp caricum p.H. Davis. J. Essent. Oil Res. 2004, 16, 133-134. [CrossRef]

171. Matos, F.J.D.; Machado, M.I.L.; Craveiro, A.A.; Alencar, J.W.; Meneses, F.D. Essential oil composition of Marsypianthes chamaedrys (vahl) kuntze grown in northeast Brazil. J. Essent. Oil Res. 2001, 13, 45-46. [CrossRef] 
172. Miceli, A.; Negro, C.; Tommasi, L. Essential oil of Melissa romana (miller) grown in southern Apulia (Italy). J. Essent. Oil Res. 2006, 18, 473-475. [CrossRef]

173. Nori-Shargh, D.; Norouzi-Arasi, H.; Mohammadi, S.; Mirza, M.; Jaimand, K. Volatile component of Mentha longifolia (L.) huds. From Iran. J. Essent. Oil Res. 2000, 12, 111-112. [CrossRef]

174. Sarikurkcu, C.; Ceylan, O.; Zeljkovic, S.C. Micromeria myrtifolia: Essential oil composition and biological activity. Nat. Prod. Commun. 2019, 14, 3. [CrossRef]

175. Chen, X.B.; Chen, R.; Luo, Z.R. Chemical composition and insecticidal properties of essential oil from aerial parts of mosla soochowensis against two grain storage insects. Trop. J. Pharm. Res. 2017, 16, 905-910. [CrossRef]

176. Talebi, S.M.; Nohooji, M.G.; Yarmohammadi, M.; Khani, M.; Matsyura, A. Effect of altitude on essential oil composition and on glandular trichome density in three nepeta species (N. Sessilifolia, N. Heliotropifolia and N. Fissa). Mediterr. Bot. 2019, 40, 81-93. [CrossRef]

177. Senatore, F.; Arnold, N.A.; Piozzi, F. Composition of the essential oil of nepeta curviflora boiss. (lamiaceae) from Lebanon. J. Essent. Oil Res. 2005, 17, 268-270. [CrossRef]

178. Raina, A.P.; Kumar, A.; Dutta, M. Chemical characterization of aroma compounds in essential oil isolated from "holy basil" (Ocimum tenuiflorum L.) grown in India. Genet. Resour. Crop Evol. 2013, 60, 1727-1735. [CrossRef]

179. Brada, M.; Saadi, A.; Wathelet, J.P.; Lognay, G. The essential oils of Origanum majorana L. and Origanum floribundum munby in Algeria. J. Essent. Oil Bear. Plants 2012, 15, 497-502. [CrossRef]

180. Van Hac, L.; Luong, N.X.; Dung, N.X.; Klinkby, N.; Leclercq, P.A. Volatile constituents of the essential oil of orthodon dianthera maxim. (syn. Mosla dianthera maxim.) from Vietnam. J. Essent. Oil Res. 2001, 13, 18-20. [CrossRef]

181. Joshi, R.K. Gc-ms analysis of the volatile constituents of orthosiphon pallidus royle, ex benth. Nat. Prod. Res. 2020, 34, 441-444. [CrossRef]

182. Ghimire, B.K.; Yoo, J.H.; Yu, C.Y.; Kim, S.H.; Chung, I.M. Profiling volatile and phenolic compound composition and characterization of the morphological and biological activities of perilla frutescence britton var. Japonica accessions. Acta Physiol. Plant. 2019, 41, 16. [CrossRef]

183. Amor, I.L.B.; Neffati, A.; Ben Sgaier, M.; Bhouri, W.; Boubaker, J.; Skandrani, I.; Bouhlel, I.; Kilani, S.; Ben Ammar, R.; Chraief, I.; et al. Antimicrobial activity of essential oils isolated from phlomis crinita cav. Ssp mauritanica munby. J. Am. Oil Chem. Soc. 2008, 85, 845-849. [CrossRef]

184. Demirci, B.; Baser, K.H.C.; Dadandi, M.Y. Composition of the essential oils of phlomis rigida labill. and Phlomis samia L. J. Essent. Oil Res. 2006, 18, 328-331. [CrossRef]

185. Tennakoon, T.; Abeysekera, A.M.; de Silva, K.T.D.; Padumadasa, C.; Wijesundara, D.S.A. Essential oil composition of Platostoma menthoides (L.) a. J. Paton whole plant. J. Essent. Oil Bear. Plants 2016, 19, 1516-1520. [CrossRef]

186. Tiwari, A.; Padalia, R.C.; Mathela, C.S. Sesquiterpene rich essential oil from Plectranthus Rugosus wall. J. Essent. Oil Bear. Plants 2008, 11, 58-61. [CrossRef]

187. Hussien, J.; Hymete, A.; Rohloff, J. Volatile constituents and biological activities of Pycnostachys Abyssinica and Pycnostachys Eminii extracts. Pharm. Biol. 2010, 48, 1384-1391. [CrossRef]

188. Apostolides, N.A.; El Beyrouthy, M.; Dhifi, W.; Najm, S.; Cazier, F.; Najem, W.; Labaki, M.; AbouKais, A. Chemical composition of aerial parts of Rosmarinus Officinalis L. Essential oil growing wild in Lebanon. J. Essent. Oil Bear. Plants 2013, 16, 274-282. [CrossRef]

189. Garcia-Rojas, A.; Fontecha-Garcia, J.; Peralta-Bohorquez, A.F.; Quijano-Celis, C.E.; Morales, G.; Pino, J.A. Composition of the essential oil from leaves and fruits of Salvia Palaefolia kunth grown in Colombia. J. Essent. Oil Res. 2010, 22, 369-370. [CrossRef]

190. Sefidkon, F.; Hooshidary, R.; Jamzad, Z. Chemical variation in the essential oil of Salvia Bracteata banks \& soland from Iran. J. Essent. Oil Bear. Plants 2007, 10, 265-272.

191. Barazandeh, M.M. Volatile constituents of the oil of Salvia Hydrangea dc. Ex benth. From Iran. J. Essent. Oil Res. 2004, 16, 20-21. [CrossRef]

192. Mirza, M.; Sefidkon, F. Essential oil composition of two salvia species from Iran, Salvia Nemorosa L. and Salvia Reuterana boiss. Flavour Frag. J. 1999, 14, 230-232. [CrossRef]

193. Sefidkon, F.; Mirza, M. Chemical composition of the essential oils of two salvia species from Iran, Salvia Virgata jacq. and Salvia Syriaca L. Flavour Frag. J. 1999, 14, 45-46. [CrossRef] 
194. Vallejo, M.C.G.; Moujir, L.; Burillo, J.; Guerra, L.L.; Gonzalez, M.; Penate, R.D.; San Andres, L.; Luis, J.G.; Blanco, F.L.; de Galarreta, C.M.R. Chemical composition and biological activities of the essential oils of Salvia Canariensis. Flavour Frag. J. 2006, 21, 277-281. [CrossRef]

195. Abak, F.; Yildiz, G.; Atamov, V.; Kurkcuoglu, M. Composition of the essential oil of Salvia Montbretii benth. From Turkey. Rec. Nat. Prod. 2018, 12, 426-431. [CrossRef]

196. Delange, D.M.; Rico, C.L.M.; Canavaciolo, V.G.; Leyes, E.A.R.; Perez, R.S. Volatile constituents from leaves of endemic Scutellaria Havanensis jacq. In Cuba. J. Essent. Oil Bear. Plants 2013, 16, 368-371. [CrossRef]

197. Yilmaz, G.; Iek, M.; Demirci, B.; Baser, K.H.C. Essential oil compositions of subspecies of Scutellaria Brevibracteata stapf from Turkey. J. Essent. Oil Res. 2019, 31, 255-262. [CrossRef]

198. Dimaki, V.D.; Iatrou, G.; Lamari, F.N. Effect of acidic and enzymatic pretreatment on the analysis of mountain tea (sideritis spp.) volatiles via distillation and ultrasound-assisted extraction. J. Chromatogr. A 2017, 1524, 290-297. [CrossRef]

199. Kirimer, N.; Tabanca, N.; Tumen, G.; Duman, H.; Baser, K.H.C. Composition of the essential oils of four endemic sideritis species from Turkey. Flavour Frag. J. 1999, 14, 421-425. [CrossRef]

200. Goren, A.C.; Piozzi, F.; Akcicek, E.; Kilic, T.; Carikci, S.; Mozioglu, E.; Setzer, W.N. Essential oil composition of twenty-two stachys species (mountain tea) and their biological activities. Phytochem. Lett. 2011, 4, 448-453. [CrossRef]

201. Kremer, D.; Bolaric, S.; Ballian, D.; Bogunic, F.; Stesevic, D.; Karlovic, K.; Kosalec, I.; Vokurka, A.; Rodriguez, J.V.; Randic, M.; et al. Morphological, genetic and phytochemical variation of the endemic Teucrium arduini L. (lamiaceae). Phytochemistry 2015, 116, 111-119. [CrossRef]

202. Baher, Z.F.; Mirza, M. Volatile constituents of Teucrium Flavum L. From Iran. J. Essent. Oil Res. 2003, 15, 106-107. [CrossRef]

203. Candela, R.G.; Ilardi, V.; Badalamenti, N.; Bruno, M.; Rosselli, S.; Maggi, F. Essential oil compositions of Teucrium Fruticans, $t$. Scordium subsp. Scordioides and $t$. Siculum growing in Sicily and Malta. Nat. Prod. Res. 2020, 10, 1-10. [CrossRef] [PubMed]

204. Blazquez, M.A.; Perez, I.; Boira, H. Essential oil analysis of Teucrium Libanitis and t-turredanum by gc and gc-ms. Flavour Frag. J. 2003, 18, 497-501. [CrossRef]

205. Brophy, J.J.; Goldsack, R.J.; Forster, P.I. The leaf essential oils of Viticipremna Queenslandica (lamiaceae). J. Essent. Oil Res. 2008, 20, 403-404. [CrossRef]

206. Konyalioglu, S.; Ozturk, B.; Meral, G.E. Comparison of chemical compositions and antioxidant activities of the essential oils of two Ziziphora Taxa from Anatolia. Pharm. Biol. 2006, 44, 121-126. [CrossRef]

207. Chaverri, C.; Ciccio, J.F.; Diaz, C. Chemical composition of Aiouea Costaricensis (lauraceae) essential oils from Costa Rica and their cytotoxic activity on cell lines. J. Essent. Oil Res. 2010, 22, 524-529. [CrossRef]

208. Salleh, W.; Ahmad, F. Antioxidant and anticholinesterase activities of essential oil of Alseodaphne Peduncularis meisn. Turk. J. Pharm. Sci. 2016, 13, 347-350. [CrossRef]

209. Luz, A.I.R.; da Silva, J.D.; Zoghbi, M.D.B.; Andrade, E.H.A.; Maia, J.G.S. Essential oil from Aniba Riparia (nees) mez. J. Essent. Oil Res. 2002, 14, 218-219. [CrossRef]

210. Salleh, W.; Ahmad, F.; Khong, H.Y.; Zulkifli, R.M. Comparative study of the essential oils of three beilschmiedia species and their biological activities. Int. J. Food Sci. Technol. 2016, 51, 240-249. [CrossRef]

211. Brophy, J.J.; Goldsack, R.J.; Forster, P.I. The essential oils of some australian Cassytha Species (lauraceae). J. Essent. Oil Res. 2009, 21, 543-546. [CrossRef]

212. Ahmed, A.; Choudhary, M.I.; Farooq, A.; Demirci, B.; Demirci, F.; Baser, K.H.C. Essential oil constituents of the spice Cinnamomum Tamala (ham.) nees \& eberm. Flavour Frag. J. 2000, 15, 388-390.

213. Son, L.C.; Dai, D.N.; Thang, T.D.; Huyen, D.D.; Ogunwande, I.A. Analysis of the essential oils from five vietnamese litsea species (lauraceae). J. Essent. Oil Bear. Plants 2014, 17, 960-971. [CrossRef]

214. Danielli, L.J.; Pippi, B.; Soares, K.D.; Duarte, J.A.; Maciel, A.J.; Machado, M.M.; Oliveira, L.F.S.; Bordignon, S.A.L.; Fuentefria, A.M.; Apel, M.A. Chemosensitization of filamentous fungi to antifungal agents using Nectandra Rol. ex rottb. species essential oils. Ind. Crop Prod. 2017, 102, 7-15. [CrossRef]

215. John, A.J.; Karunakaran, V.P.; George, V. Chemical composition and antibacterial activity of leaf oil of Neolitsea foliosa (nees) gamble var. caesia (meisner) gamble. J. Essent. Oil Res. 2007, 19, 498-500. [CrossRef]

216. Barbosa, J.M.; Cunha, R.M.; Dias, C.S.; Athayde, P.F.; Silva, M.S.; Da-Cunha, E.V.L.; Machado, M.I.L.; Craveiro, A.A.; Medeiros, I.A. Gc-ms analysis and cardiovascualr activity of the essential oil of Ocotea Duckei. J. Pharmacogn. 2008, 18, 37-41. 
217. Yamaguchi, K.K.D.; Alcantara, J.M.; Lima, E.S.; da Veiga, V.F. Chemical composition and platelet aggregation activity of essential oils of two species of the Genus Ocotea (lauraceae). J. Essent. Oil Bear. Plants 2013, 16, 518-523. [CrossRef]

218. Ogunbinu, A.O.; Ogunwande, I.A.; Flamini, G.; Cioni, P.L. Volatile compounds of Persea Americana mill from Nigeria. J. Essent. Oil Bear. Plants 2007, 10, 133-138. [CrossRef]

219. Lopez, M.L.; Zunino, M.P.; Zygadlo, J.A.; Lopez, A.G.; Lucini, E.I.; Facillaci, S.M. Aromatic plants of yungas. Part ii. Chemical composition of the essential oil of Phoebe Porphyria (griseb.) mez. (lauraceae). J. Essent. Oil Res. 2004, 16, 129-130. [CrossRef]

220. Miyazawa, M.; Nakashima, Y.; Nakahashi, H.; Hara, N.; Nakagawa, H.; Usami, A.; Chavasiri, W. Volatile compounds with characteristic odor of essential oil from Magnolia Obovata leaves by hydrodistillation and solvent-assisted flavor evaporation. J. Oleo Sci. 2015, 64, 999-1007. [CrossRef]

221. Lawal, O.A.; Ogunwande, I.A.; Salvador, A.F.; Sanni, A.A.; Opoku, A.R. Pachira Glabra Pasq. essential oil: Chemical constituents, antimicrobial and insecticidal activities. J. Oleo Sci. 2014, 63, 629-635. [CrossRef]

222. Mevy, J.P.; Bessiere, J.M.; Rabier, J.; Dherbomez, M.; Ruzzier, M.; Millogo, J.; Viano, J. Composition and antimicrobial activities of the essential oil of Triumfetta Rhomboidea jacq. Flavour Frag. J. 2006, 21, 80-83. [CrossRef]

223. Joycharat, N.; Thammavong, S.; Voravuthikunchai, S.P.; Plodpai, P.; Mitsuwan, W.; Limsuwan, S.; Subhadhirasakul, S. Chemical constituents and antimicrobial properties of the essential oil and ethanol extract from the stem of Aglaia odorata lour. Nat. Prod. Res. 2014, 28, 2169-2172. [CrossRef] [PubMed]

224. Rahman, M.S.; Ahad, A.; Saha, S.K.; Hong, J.; Kim, K.H. Antibacterial and phytochemical properties of Aphanamixis polystachya essential oil. Anal. Sci. Technol. 2017, 30, 113-121.

225. Lago, J.H.G.; de Avila, P.; de Aquino, E.M.; Moreno, P.R.H.; Ohara, M.T.; Limberger, R.P.; Apel, M.A.; Henriques, A.T. Volatile oils from leaves and stem barks of Cedrela fissilis (meliaceae): Chemical composition and antibacterial activities. Flavour Frag. J. 2004, 19, 448-451. [CrossRef]

226. Ribeiro, W.H.F.; Arriaga, A.M.C.; Andrade-Neto, M.; Vasconcelos, J.N.; Santiago, G.M.P.; Nascimento, R.F. Composition of the essential oil of Guarea macrophylla vahl. ssp tuberculata (meliaceae) from northeast of Brazil. J. Essent. Oil Res. 2006, 18, 95-96. [CrossRef]

227. Ogunwande, I.A.; Jimoh, R.; Ajetunmobi, A.A.; Avoseh, N.O.; Flamini, G. Essential oil composition of Ficus benjamina (moraceae) and Irvingia barteri (irvingiaceae). Nat. Prod. Commun. 2012, 7, 1673-1675. [CrossRef]

228. St-Gelais, A.; Roger, B.; Alsarraf, J.; Legault, J.; Masse, D.; Pichette, A. Aromas from Quebec. Vi. Morella pensylvanica from the Magdalen Islands: A (-)-alpha-bisabolol-rich oil featuring a new bisabolane ether. J. Essent. Oil Res. 2018, 30, 319-329. [CrossRef]

229. Sabulal, B.; Kurup, R.; Sumitha, B.; George, V. Chemical composition of the leaf oils of Myristica malabarica lam. and Gymnacranthera canarica (king) warb. J. Essent. Oil Res. 2007, 19, 323-325. [CrossRef]

230. Salleh, W.; Anuar, M.Z.A.; Khamis, S.; Nafiah, M.A.; Sul'ain, M.D. Chemical investigation and biological activities of the essential oil of Knema kunstleri warb. from Malaysia. Nat. Prod. Res. 2019. [CrossRef]

231. Limberger, R.P.; Sobral, M.E.G.; Zuanazzi, J.A.S.; Moreno, P.R.H.; Schapoval, E.E.S.; Henriques, A.T. Biological activities and essential oil composition of leaves of Blepharocalyx salicifolius. Pharm. Biol. 2001, 39, 308-311. [CrossRef]

232. Bignell, C.M.; Dunlop, P.J.; Brophy, J.J.; Jackson, J.F. Volatile leaf oils of some queensland and northern australian species of the Genus eucalyptus. (series ii). Part i. Subgenus symphyomyrtus, section adnataria: (a) series oliganthae, (b) series ochrophloiae, (c) series moluccanae, (d) series polyanthemae, (e) series paniculatae, (f) series melliodorae and (g) series porantheroideae. Flavour Frag. J. 1997, 12, 19-27.

233. Medeiros, J.R.; Medeiros, N.; Medeiros, H.; Davin, L.B.; Lewis, N.G. Composition of the bioactive essential oils from the leaves of eugenia stipitata mcvaugh ssp sororia from the Azores. J. Essent. Oil Res. 2003, 15, 293-295. [CrossRef]

234. Fernandez, X.; Loiseau, A.M.; Poulain, S.; Lizzani-Cuvelier, L.; Monnier, Y. Chemical composition of the essential oil from feijoa (feijoa sellowiana berg.) peel. J. Essent. Oil Res. 2004, 16, 274-275. [CrossRef]

235. Limberger, R.P.; Simoes-Pires, C.A.; Sobral, M.; Henriques, A.T. Essential oils of marlierea species. J. Essent. Oil Res. 2004, 16, 479-482. [CrossRef]

236. Hnawia, E.; Brophy, J.J.; Craven, L.A.; Lebouvier, N.; Cabalion, P.; Nour, M. An examination of the leaf essential oils of the Endemic melaleuca (myrtaceae) species of New Caledonia. J. Essent. Oil Res. 2012, 24, 273-278. [CrossRef] 
237. Zoghbi, M.D.; Andrade, E.H.A.; da Silva, M.H.L.; Carreira, L.M.M.; Maia, J.G.S. Essential oils from three myrcia species. Flavour Frag. J. 2003, 18, 421-424. [CrossRef]

238. Demo, M.S.; Oliva, M.M.; Zunino, M.R.; Lopez, M.L.; Zygadlo, J.A. Aromatic plants from Yungas. Part iv: Composition and antimicrobial activity of myrcianthes pseudo-mato essential oil. Pharm. Biol. 2002, 40, 481-484. [CrossRef]

239. Apel, M.A.; Lima, M.E.L.; Sobral, M.; Young, M.C.M.; Cordeiro, I.; Schapoval, E.E.S.; Henriques, A.T.; Moreno, P.R.H. Anti-inflammatory activity of essential oil from leaves of Myrciaria tenella and Calycorectes sellowianus. Pharm. Biol. 2010, 48, 433-438. [CrossRef]

240. Southwell, I.A.; Russell, M.F.; Smith, R.L.; Vinnicombe, A. Ochrosperma lineare, a new source of methyl chavicol. J. Essent. Oil Res. 2003, 15, 329-330. [CrossRef]

241. Apel, M.A.; Sobral, M.; Zuanazzi, J.A.; Henriques, A.T. Essential oil composition of four plinia species (myrtaceae). Flavour Frag. J. 2006, 21, 565-567. [CrossRef]

242. Da Silva, J.D.; Luz, A.I.R.; da Silva, M.H.L.; Andrade, E.H.A.; Zoghbi, M.D.; Maia, J.G.S. Essential oils of the leaves and stems of four psidium spp. Flavour Frag. J. 2003, 18, 240-243. [CrossRef]

243. El Ghallab, Y.; Al Jahid, A.; Eddine, J.J.; Said, A.A.H.; Zarayby, L.; Derfoufi, S. Syzygium aromaticum 1.: Phytochemical investigation and comparison of the scavenging activity of essential oil, extracts and eugenol. Adv. Tradit. Med. 2020, 20, 153-158. [CrossRef]

244. Huong, L.T.; Hung, N.V.; Chac, L.D.; Dai, D.N.; Ogunwande, I.A. Essential oils from Syzygium grande (wight) walp. and syzygium sterrophyllum merr. et perry. J. Essent. Oil Bear. Plants 2017, 20, 1620-1626. [CrossRef]

245. Brophy, J.J.; Goldsack, R.J.; Forster, P.I. The essential oils of the australian species of uromyrtus (myrtaceae). Flavour Frag. J. 1996, 11, 133-138. [CrossRef]

246. Rustaiyan, A.; Khalilzadeh, M.A.; Eslami, B.; Masoudi, S.; Tajbakhsh, M. Volatile constituents of Meristotropis xanthioides vassilez. and Lotus michauxianus ser. from Iran. J. Essent. Oil Res. 2006, 18, 631-632. [CrossRef]

247. Dai, D.N.; Thang, T.D.; Thin, D.B.; Ogunwande, I.A. Chemical composition of the leaf oil of actephila excelsa from Vietnam. Nat. Prod. Commun. 2014, 9, 1359-1360. [CrossRef]

248. Yu, E.J.; Kim, T.H.; Kim, K.H.; Lee, H.J. Characterization of aroma-active compounds of Abies nephrolepis (khingan fir) needles using aroma extract dilution analysis. Flavour Frag. J. 2004, 19, 74-79. [CrossRef]

249. Hmamouchi, M.; Hamamouchi, J.; Zouhdi, M.; Bessiere, J.M. Chemical and antimicrobial properties of essential oils of five Moroccan pinaceae. J. Essent. Oil Res. 2001, 13, 298-302. [CrossRef]

250. Tsitsimpikou, C.; Petrakis, P.V.; Ortiz, A.; Harvala, C.; Roussis, V. Volatile needle terpenoids of six pinus species. J. Essent. Oil Res. 2001, 13, 174-178. [CrossRef]

251. Jeon, J.H.; Lee, H.S. Volatile components of essential oils extracted from pinus species. J. Essent. Oil Bear. Plants 2012, 15, 750-754. [CrossRef]

252. Yener, H.O.; Saygideger, S.D.; Sarikurkcu, C.; Yumrutas, O. Evaluation of antioxidant activities of essential oils and methanol extracts of pinus species. J. Essent. Oil Bear. Plants 2014, 17, 295-302. [CrossRef]

253. Facundo, V.A.; de Morais, S.M. Essential oil of Piper tuberculatum var. Tuberculatum pip (micq.) cdc leaves. J. Essent. Oil Res. 2005, 17, 304-305. [CrossRef]

254. Jirovetz, L.; Buchbauer, G.; Ngassoum, M.B.; Geissler, M. Aroma compound analysis of Piper nigrum and piper guineense essential oils from Cameroon using solid-phase microextraction-gas chromatography, solid-phase microextraction-gas chromatography-mass spectrometry and olfactometry. J. Chromatogr. A 2002, 976, 265-275. [CrossRef]

255. Menon, A.N.; Padmakumari, K.P.; Jayalekshmy, A.; Gopalakrishnan, M.; Narayanan, C.S. Essential oil composition of four popular Indian cultivars of black pepper (Piper nigrum L.). J. Essent. Oil Res. 2000, 12, 431-434. [CrossRef]

256. Sirat, H.M.; Thai, O.B.; Ahmad, F. Chemical composition of the essential oil of Piper maingayi hk. F. J. Essent. Oil Res. 2010, 22, 323-324. [CrossRef]

257. Moraes, M.S.; Machado, S.R.; Marques, M.O.M. Essential oil of the Pothomorphe peltata (L.) miq. J. Essent. Oil Res. 2004, 16, 15-16. [CrossRef]

258. Zeng, Z.; Meng, C.Y.; Ye, X.N.; Zeng, Z. Analysis of volatile components of adenosma Indianum (lour.) merr. by steam distillation and headspace solid-phase microextraction. J. Chem. 2013, 2013, 1-7. [CrossRef] 
259. Martins, A.P.; Salgueiro, L.R.; Cavaleiro, C.; da Cunha, A.P.; Tomi, F.; Casanova, J. Chemical composition of the oil of Afrocarpus mannii, an endemic species from s.tome e principe. J. Essent. Oil Res. 2001, 13, 431-433. [CrossRef]

260. Cavalli, J.F.; Tomi, F.; Bernardini, A.F.; Casanova, J. Composition and chemical variability of the bark oil of Cedrelopsis grevei h. baillon from Madagascar. Flavour Frag. J. 2003, 18, 532-538. [CrossRef]

261. Navaei, M.N.; Mirza, M. A comparative study of the essential oils of Agrimonia eupatoria both cultivated and wild growing conditions in Iran. J. Essent. Oil Bear. Plants 2009, 12, 369-373. [CrossRef]

262. Ghazghazi, H.; Miguel, M.G.; Weslati, M.; Hasnaoui, B.; Sebei, H.; Barroso, J.G.; Pedro, L.G.; Figueiredo, A.C. Chemical variability of the essential oils from Rosa canina L. and Rosa sempervirens L. Flowers collected at Tunisia. J. Essent. Oil Res. 2012, 24, 475-480. [CrossRef]

263. Tava, A.; Biazzi, E.; Ronga, D.; Avato, P. Identification of the volatile components of Galium verum L. and Cruciata leavipes opiz from the western Italian Alps. Molecules 2020, 25, 11. [CrossRef] [PubMed]

264. Rao, H.J.Z.; Lai, P.X.; Gao, Y. Chemical composition, antibacterial activity, and synergistic effects with conventional antibiotics and nitric oxide production inhibitory activity of essential oil from Geophila repens (1.) imjohnst. Molecules 2017, 22, 13.

265. Pant, P.; Sut, S.; Castagliuolo, I.; Gandin, V.; Maggi, F.; Gyawali, R.; Stefano, D. Sesquiterpene rich essential oil from nepalese bael tree (Aegle marmelos (1.) correa) as potential antiproliferative agent. Fitoterapia 2019, 138, 6. [CrossRef] [PubMed]

266. Pino, J.A.; Rosado, A.; Bello, A.; Urquiola, A.; Garcia, S. Essential oil of Amyris elimifera L. from Cuba. J. Essent. Oil Res. 2000, 12, 39-40. [CrossRef]

267. Pang, X.; Almaz, B.; Qi, X.J.; Wang, Y.; Feng, Y.X.; Geng, Z.F.; Xi, C.; Du, S.S. Bioactivity of essential oil from Atalantia buxifolia leaves and its major sesquiterpenes against three stored-product insects. J. Essent. Oil Bear. Plants 2020, 23, 38-50. [CrossRef]

268. Padalia, R.C.; Verma, R.S.; Chauhan, A. Compositional variations in volatile constituents of Boenninghausenia albiflora reichb. from western Himalaya. Natl. Acad. Sci. Lett. 2013, 36, 635-640. [CrossRef]

269. Brophy, J.J.; Goldsack, R.J.; Forster, P.I. The leaf oils of the australian species of citrus (rutaceae). J. Essent. Oil Res. 2001, 13, 264-268. [CrossRef]

270. Supudompol, B. Composition and anti-mycobacterial activity of the essential oil of Feroniella lucida (scheff.) swing. J. Essent. Oil Res. 2009, 21, 561-562. [CrossRef]

271. Brophy, J.J.; Goldsack, R.J.; Forster, P.I. The leaf oils of the australian species of flindersia (rutaceae). J. Essent. Oil Res. 2005, 17, 388-395. [CrossRef]

272. Azadi, B.; Khaef, S.; Ziarati, P. Chemical composition of Haplophyllum villosum (m. B.) g. don essential oil. J. Essent. Oil Bear. Plants 2014, 17, 1161-1164. [CrossRef]

273. Brophy, J.J.; Goldsack, R.J.; Forster, P.I. The leaf oils of the australian species of medicosma (rutaceae). J. Essent. Oil Res. 2004, 16, 161-166. [CrossRef]

274. Brophy, J.J.; Goldsack, R.J.; Forster, P.I. Composition of the leaf oils of the australian species of euodia and melicope (rutaceae). J. Essent. Oil Res. 2004, 16, 286-293. [CrossRef]

275. Neta, M.C.S.; Vittorazzi, C.; Guimaraes, A.C.; Martins, J.D.L.; Fronza, M.; Endringer, D.C.; Scherer, R. Effects of beta-caryophyllene and Murraya paniculata essential oil in the murine hepatoma cells and in the bacteria and fungi 24-h time-kill curve studies. Pharm. Biol. 2017, 55, 190-197. [CrossRef]

276. Padmakumari, K.P. Volatile constituents from the leaves and flowers of Murraya koenigii (linn.) spreng. J. Essent. Oil Bear. Plants 2009, 12, 722-727. [CrossRef]

277. Pavithra, P.S.; Mehta, A.; Verma, R.S. Induction of apoptosis by essential oil from p. Missionis in skin epidermoid cancer cells. Phytomedicine 2018, 50, 184-195.

278. Cabral, F.D.; Alves, C.C.F.; Cabral, R.S.C.; Willrich, G.B.; Crotti, A.E.M.; MIranda, M.L.D. Chemical constituents of essential oils extracted from the leaves and flowers of Spiranthera odoratissima a. st. hil. (rutaceae). Rec. Nat. Prod. 2019, 13, 172-175. [CrossRef]

279. Brophy, J.J.; Goldsack, R.J.; Forster, P.I.; Hutton, I. Composition of the leaf oils of the australian and lord howe island species of zanthoxylum (rutaceae). J. Essent. Oil Res. 2000, 12, 285-291. [CrossRef]

280. Song, X.H.; Li, H.; Li, C.R.; Xu, J.W.; Hu, D.M. Effects of vocs from leaves of Acer truncatum bunge and Cedrus deodara on human physiology and psychology. Urban For. Urban Green. 2016, 19, 29-34. [CrossRef] 
281. Rehman, J.U.; Wang, M.; Yang, Y.P.; Liu, Y.B.; Li, B.; Qin, Y.; Wang, W.; Chittiboyina, A.G.; Khan, I.A. Toxicity of Kadsura coccinea (lem. ) a. C. Sm. Essential oil to the bed bug, Cimex lectularius L. (hemiptera: Cimicidae). Insects 2019, 10, 11. [CrossRef]

282. Garg, S.C.; Dengre, S.L. Composition of the essential oil from the leaves of Buddleia asiatica lour. Flavour Frag. J. 1992, 7, 125-127. [CrossRef]

283. Fonseca, A.M.; Pessoa, O.D.L.; Lemos, T.L.G.; Nascimento, R.F. Constituents of the essential oil of capraria biflora from northeast Brazil. J. Essent. Oil Res. 2006, 18, 158-159. [CrossRef]

284. Osorio, A.M.B.; Silva, T.M.; Duarte, L.P.; Ferraz, V.P.; Pereira, M.T.; Mercadante-Simoes, M.O.; Evangelista, F.C.G.; Sabino, A.P.; Alcantara, A.F.C. Essential oil from flowers of solanum stipulaceum: Composition, effects of gamma-radiation, and antileukemic activity. J. Braz. Chem. Soc. 2015, 26, 2233-2240.

285. Pino, J.A.; Marbot, R.; Fuentes, V. Essential oil of Aloysia virgata juss. from Cuba. J. Essent. Oil Res. 2004, 16, 44-45. [CrossRef]

286. Sousa, E.O.; Rodrigues, F.F.G.; Coutinho, H.D.M.; Campos, A.R.; Lima, S.G.; Costa, J.G.M. Chemical composition and aminoglycosides synergistic effect of Lantana montevidensis briq. (verbenaceae) essential oil. Rec. Nat. Prod. 2011, 5, 60-64.

287. Randrianalijaona, J.A.; Ramanoelina, P.A.R.; Rasoarahona, J.R.E.; Gaydou, E.M. Seasonal and chemotype influences on the chemical composition of Lantana camara L. essential oils from Madagascar. Anal. Chim. Acta 2005, 545, 46-52. [CrossRef]

288. Vila, R.; Iglesias, J.; Canigueral, S.; Ciccio, J.F. Composition of the essential oil from leaves of lippia myriocephala from Costa Rica. J. Essent. Oil Res. 2004, 16, 177-179. [CrossRef]

289. Baez, D.; Pino, J.A.; Morales, D. Floral scent composition in Petitia domingensis jacq. Analyzed by hs-spme. J. Essent. Oil Bear. Plants 2012, 15, 782-784. [CrossRef]

290. Eyob, S.; Appelgren, M.; Rohloff, J.; Tsegaye, A.; Messele, G. Traditional medicinal uses and essential oil composition of leaves and rhizomes of korarima (Aframomum corrorima (braun) p.C.M. Jansen) from southern Ethiopia. S. Afr. J. Bot. 2008, 74, 181-185. [CrossRef]

291. Ali, S.; Sotheeswaran, S.; Tuiwawa, M.; Smith, R.M. Comparison of the composition of the essential oils of alpinia and hedychium species-Essential oils of fijian plants, part 1. J. Essent. Oil Res. 2002, 14, 409-411. [CrossRef]

292. Wong, K.C.; Lee, B.C.; Lam, N.F.; Ibrahim, P. Essential oils of the rhizomes of Alpinia conchigera griff. and Alpinia latilabris ridl. Flavour Frag. J. 2005, 20, 431-433. [CrossRef]

293. Huong, L.T.; Dai, D.N.; Thang, T.D.; Bach, T.T.; Ogunwande, I.A. The essential oils of the leaf, pseudostem root and fruit of Alpinia mutica roxb. J. Essent. Oil Bear. Plants 2016, 19, 2049-2055. [CrossRef]

294. Huong, L.T.; Dai, D.N.; Thang, T.D.; Bach, T.T.; Ogunwande, I.A. Analysis of the volatile constituents of alpinia pinnanensis. J. Essent. Oil Bear. Plants 2017, 20, 264-271. [CrossRef]

295. Taiwo, A.O.; Bolanle, A.A. The leaf essential oil of costus afer ker-grawl from Nigeria. Flavour Frag. J. 2003, 18, 309-311. [CrossRef]

296. Raina, V.K.; Srivastava, S.K.; Jain, N.; Ahmad, A.; Syamasundar, K.V.; Aggarwal, K.K. Essential oil composition of Curcuma longa L. Cv. Roma from the plains of northern India. Flavour Frag. J. 2002, 17, 99-102. [CrossRef]

297. Wong, K.C.; Sivasothy, Y.; Boey, P.L.; Osman, H.; Sulaiman, B. Essential oils of Etlingera elatior (jack) r. M. Smith and Etlingera littoralis (koenig) giseke. J. Essent. Oil Res. 2010, 22, 461-466. [CrossRef]

298. Raj, G.; George, V.; Dan, M.; Sethuraman, M.G. Essential oil composition of Globba schomburgkii hook. F. and Globba ophioglossa wight. J. Essent. Oil Res. 2010, 22, 220-222. [CrossRef]

299. Dos Santos, B.C.B.; Barata, L.E.S.; Marques, F.A.; Baroni, A.C.M.; Karnos, B.A.C.; de Oliveira, P.R.; Guerrero, P.G. Composition of leaf and rhizome essential oils of Hedychium coronarium koen. from Brazil. J. Essent. Oil Res. 2010, 22, 305-306. [CrossRef]

300. Gevu, K.V.; Limag, H.R.P.; Neves, B.A.; Mello, E.O.; Taveirag, G.B.; Carvalhoa, L.P.; Carvalho, M.G.; Gomes, V.M.; Melo, E.J.T.; Da Cunha, M. Chemical composition and anti-candida and anti-trypanosoma cruzi activities of essential oils from the rhizomes and leaves of Brazilian species of renealmia l. Fil. Rec. Nat. Prod. 2019, 13, 268-280. [CrossRef]

301. Maia, J.G.S.; Andrade, E.H.A.; Carreira, L.M.M.; da Silva, M.H.L. Essential oil composition of Renealmia alpinia (rottb.) maas. J. Essent. Oil Bear. Plants 2007, 10, 10-14. [CrossRef] 
302. Sabulal, B.; Dan, M.; Anil, J.J.; Kurup, R.; Pradeep, N.S.; Valsamma, R.K.; George, V. Caryophyllene-rich rhizome oil of zingiber nimmonii from south India: Chemical characterization and antimicrobial activity. Phytochemistry 2006, 67, 2469-2473. [CrossRef] [PubMed]

303. Barra, A. Factors affecting chemical variability of essential oils: A review of recent developments. Nat. Prod. Commun. 2009, 4, 1147-1154. [CrossRef] [PubMed]

304. Gad, H.A.; El-Ahmady, S.H.; Abou-Shoer, M.I.; Al-Azizi, M.M. Application of chemometrics in authentication of herbal medicines: A review. Phytochem. Anal. 2013, 24, 1-24. [CrossRef] [PubMed]

305. Maffei, M.E. Plant Bioactive Molecules; Cambridge Scholars Publishing: Newcastle upon Tyne, UK, 2018.

306. Soni, U.; Brar, S.; Gauttam, V.K. Effect of seasonal variation on secondary metabolites of medicinal Plants. Int. J. Pharmacol. Sci. Res. 2015, 6, 3654-3662.

307. Xavier, F.H.; Maciuk, A.; Morais, A.R.D.; Alencar, E.D.; Garcia, V.L.; do Egito, E.S.T.; Vauthier, C. Development of a gas chromatography method for the analysis of copaiba oil. J. Chromatogr. Sci. 2017, 55, 969-978. [CrossRef]

308. Sousa, J.P.B.; Brancalion, A.P.S.; Souza, A.B.; Turatti, I.C.C.; Ambrosio, S.R.; Furtado, N.; Lopes, N.P.; Bastos, J.K. Validation of a gas chromatographic method to quantify sesquiterpenes in copaiba oils. J. Pharm. Biomed. Anal. 2011, 54, 653-659. [CrossRef]

309. Junor, G.A.O.; Porter, R.B.R.; Yee, T.H. Chemical composition of essential oils from the aerial parts of jamaican bursera lunanii spreng. J. Essent. Oil Res. 2010, 22, 602-605. [CrossRef]

310. Temel, M.; Tinmaz, A.B.; Ozturk, M.; Gunduz, O. Production and trade of medicinal and aromatic plants in the world and Turkey. Ksu Tarim Ve Doga Dergisi-Ksu J. Agric. Nat. 2018, 21, 198-214.

311. Klauke, A.L.; Racz, I.; Pradier, B.; Markert, A.; Zimmer, A.M.; Gertsch, J.; Zimmer, A. The cannabinoid $\mathrm{cb}(2)$ receptor-selective phytocannabinoid beta-caryophyllene exerts analgesic effects in mouse models of inflammatory and neuropathic pain. Eur. Neuropsychopharmacol. 2014, 24, 608-620. [CrossRef]

312. Chicca, A.; Caprioglio, D.; Minassi, A.; Petrucci, V.; Appendino, G.; Taglialatela-Scafati, O.; Gertsch, J. Functionalization of beta-caryophyllene generates novel polypharmacology in the endocannabinoid system. ACS Chem. Biol. 2014, 9, 1499-1507. [CrossRef] 